Gamma exposure from building materials - A dose model with expanded gamma lines from naturally occurring radionuclides applicable in non-standard rooms

Peer-reviewed author version

CROYMANS-PLAGHKI, Tom; Leonardi, Federica; Trevisi, Rosabianca; Nuccetelli, Cristina; SCHREURS, Sonja \& SCHROEYERS, Wouter (2018) Gamma exposure from building materials - A dose model with expanded gamma lines from naturally occurring radionuclides applicable in non-standard rooms. In: CONSTRUCTION AND BUILDING MATERIALS, 159, p. 768-778.

DOI: 10.1016/j.conbuildmat.2017.10.051

Handle: http://hdl.handle.net/1942/25403 


\title{
Gamma exposure from building materials - a dose model with expanded gamma lines from Naturally Occurring Radionuclides applicable in non-standard rooms.
}

\author{
Tom Croymans ${ }^{1}$, Federica Leonardi ${ }^{2}$, Rosabianca Trevisi ${ }^{2}$, Cristina Nuccetelli ${ }^{3}$, Sonja \\ Schreurs ${ }^{1}$, Wouter Schroeyers ${ }^{1}$ \\ ${ }^{1}$ Hasselt University, CMK, NuTeC, Nuclear Technology - Faculty of Engineering Technology, \\ Agoralaan building H, B-3590 Diepenbeek, Belgium \\ 2 INAIL (National Institute for Insurance against Accidents at Work) - Research Sector, \\ DiMEILA, Via di Fontana Candida 100078 Monteporzio Catone (Rome), Italy \\ ${ }^{3}$ ISS (National Institute of Health), Technology and Health Department, Viale Regina Elena, \\ 299, Rome, Italy \\ *Corresponding author: wouter.schroeyers@uhasselt.be \\ Tel: +32112921 57 \\ * Hasselt University, NuTeC, CMK, Nuclear Technology - Faculty of Engineering Technology, \\ Agoralaan building H, B-3590 Diepenbeek, Belgium
}

\section{Keywords}

Euratom Basic Safety Standards; Dose Models; Naturally Occurring Radionuclides; Naturally Occurring Radioactive Materials; Radioactivity; Building materials; Concrete; Inorganic polymers; Alkali-activated materials; External gamma exposure

\section{Abstract}

Building materials are a significant source of gamma rays exposure due to the presence of naturally occurring radionuclides. In order to protect the public from harmful radiation, the European Basic Safety Standards (Council directive 2013/59/Euratom) introduced a one-sizefits-all building(s) (materials) Activity Concentration Index ( $\mathrm{ACl}$ ) based on a limited set of gamma lines. The $\mathrm{ACl}$ is considered "as a conservative screening tool for identifying materials that may cause the reference level (i.e. $1 \mathrm{msv} / \mathrm{y}$ ) laid down in Article 75(1) to be exceeded". Regarding calculation of dose, many factors such as density and thickness of the building material, as well as factors relating to the type of building, and the gamma emission data need to be taking into account to ensure accurate radiation protection. In this study the implementation of an expanded set of 1845 gamma lines, related to the decay series of ${ }^{238} \mathrm{U}$, ${ }^{235} \mathrm{U}$ and ${ }^{232} \mathrm{Th}$ as well as to ${ }^{40} \mathrm{~K}$, into the calculation method of Markkanen [1], is discussed. The expanded calculation method is called the Expanded Gamma Dose Assessment (EGDA) model. The total gamma emission intensity increased from 2.12 to 2.41 and from 2.41 to 3.04 for respectively the ${ }^{238} \mathrm{U}$ and ${ }^{232} \mathrm{Th}$ decay series. In case of ${ }^{40} \mathrm{~K}$ a decrease from 0.107 to 0.1055 is observed. The ${ }^{235} \mathrm{U}$ decay series is added, having a gamma emission intensity of 3.1 . In a standard concrete room, the absorbed dose rates in air $\left(D_{A}\right)$ per unit of activity concentration of $0.849,0.256,1.08,0.0767 \mathrm{nGy} / \mathrm{h}$ per $\mathrm{Bq} / \mathrm{kg}$ are observed. The use of weighted average gamma lines increased the $D_{A}$ with $6.5 \%$ and $1 \%$ for respectively the ${ }^{238} \mathrm{U}$ and ${ }^{232} \mathrm{Th}$ decay series. A decrease of $4.5 \%$ is observed in the $D_{A}$ of ${ }^{235} \mathrm{U}$ decay series when using the weighted average gamma lines in comparison to its non-averaged variant. The sensitivity of the EGDA model for density, wall thickness, presence of windows and doors and room size is investigated. Finally, a comparison of the index and dose calculations relevant for the dose 
assessment within the European legislative framework applicable towards building materials is performed. In cases where the $\mathrm{ACl}$ and density and thickness corrected dose calculation of Nuccetelli et al. [2] cannot provide guidance, the EGDA allows performing more accurate dose assessment calculations leading to effective doses which can be several $100 \mu \mathrm{Sv} / \mathrm{y}$ lower.

\section{Introduction}

Building materials are a significant source of indoor gamma dose [3]. The importance to address the exposure originating from building materials is underlined in article 75 of the Euratom basic safety standards (EU-BSS) (Council directive 2013/59/Euratom) which comes into force in February 2018 [4]. This article states that "The reference level applying to indoor external exposure to gamma radiation emitted by building materials, in addition to outdoor external exposure, shall be $1 \mathrm{mSv}$ per year". This European legislation was developed to establish basic standards, applicable in EU member states, for the protection against exposure of ionising radiation for workers and the general public. In a broader context this legislation supports several launched initiatives of the European commission for turning waste into a resource and promoting re-use and recycling with focus on the building industry in the framework of the Europe 2020 strategy [5-7]. In this context the EU-BSS aims towards a safe use of by-products, originating from NORM (Naturally Occurring Radioactive Material)processing industries, like metallurgical slags, fly and bottom ash, phosphogypsum and red mud. These residues are used or investigated to use in cement-based matrixes as supplementary cementitious materials (SCM) on a large scale [8-12]. In addition more and more research is conducted to use these residues in more $\mathrm{CO}_{2}$-friendly cement alternatives, like inorganic polymers (IPs) [8-10]. This fits with the aim to reduce the usage of primary resources. It is expected that future building materials used for dwellings will shift more and more towards these secondary raw materials that can potentially be rich in naturally occurring radionuclides (NORs): therefore the impact on the external gamma exposure of the use of these secondary raw materials needs to be assessed $[10,13,14]$.

In order to assess the impact on external gamma exposure of building materials, different calculation methods, based on Monte Carlo simulations, integration and simple index and dose formulas, have been developed in the past [1,15-26]. Different dose assessment calculations have been developed based on gamma ray attenuation and build-up factors $[1,16,17,22,27]$. These calculations allow specifying the physical parameters of the room and the material it is constructed out, in a straightforward way. The density and wall thickness are identified as the most critical parameters. Modifying these parameters, for the evaluation of non-standard rooms, can generate dose rate differences up to $40 \%$ compared to a standard concrete room [27]. Seeking for a standardized approach, the EU-BSS proposes a screening index, named Activity Concentration Index (ACl) [2]. This index was originally developed by Markkanen [1] and is described in the technical guide Radiation Protection (RP)-112 [28]. The $\mathrm{ACl}$ is based on a number of assumptions that are not all necessarily valid. The $\mathrm{ACl}$ assumes a concrete room $\left(400 \mathrm{~cm} \times 500 \mathrm{~cm} \times 280 \mathrm{~cm}\right.$ ) with a density of $2350 \mathrm{~kg} / \mathrm{m}^{3}$ and thickness of 20 $\mathrm{cm}$ for all surfaces (walls, floor and ceiling). In the last years, in order to get a reliable screening tool, that will allow for a realistic discrimination of building materials, a new density and thickness corrected index I( $\rho d)$ was developed by Nuccetelli et al. [2]. The available dose assessment models focus on the standard composition of concrete, however the increased usage of residues, which have an a priori chemical compositions differing from conventional 
raw materials (like OPC and gravel), can result in structures with very different compositions. Some models consequently apply a correction factor to compensate for the different composition [29]. In addition, disequilibrium in the ${ }^{238} \mathrm{U}$ and ${ }^{232} \mathrm{Th}$ decay series chain can be present for residues from NORM-processing industries. Information regarding disequilibrium can be valuable for gaining insight into environmental or industrial processes. However, when dealing with the dose assessments of building materials one should assess how meaningful the consideration of disequilibrium is. Up to now, to the authors' knowledge, in none of the existing dose calculations, disequilibrium situations are taken into account. In contrast RP-122 [30]suggests using the highest activity concentration of a radionuclide present in a certain decay series to specify the activity concentration of that whole decay series. In none of the existing tools the presence of ${ }^{235} \mathrm{U}$ and its decay products is considered.

The above mentioned calculation methods have in common that they only use a fraction of the gamma emission lines known today. In practice, this means that often dose models use a specific set of major gamma lines or that the set of several major gamma lines is reduced to one or several averaged gamma lines with the gamma intensity as weighing factor. Whereas the gamma emission intensity of this averaged gamma line is the sum of the individual gamma emission intensities. This technique is performed to provide simplicity. However progress has been made in the characterization of the gamma emissions of radionuclides. The Laboratoire National Henri Becquerel has built an online database providing continuously updated information on the gamma emission lines of a wide range of radionuclides that allows going beyond this simplified approach [31]. Implementation of this database into a dose calculation method allows a more accurate safety assessment to evaluate if construction products can be used from a radiation protection point of view [2]. Both sample parameters, like density and composition, as well as room parameters like thickness of the walls, ceiling and floor, number of walls present, the sample composition of each wall etc. impact the final received dose $[15,27]$. An adaptable dose assessment calculation allows taking these parameters into account.

Using an flexible dose or index calculation, in contrast to a screening index, for the evaluation of building materials fits better with the $1 \mathrm{mSv}$ dose requirement of article 75 of the EU-BSS [2], in particular when dealing with non-standard room and building material parameters. In addition the implementation of non-standard room and building material parameters deals with the requirement of annex VII of the EU-BSS, that states "The calculation of dose needs to take into account other factors such as density, thickness of the material as well as factors relating to the type of building and the intended use of the material (bulk or superficial)". The current study implements improvements, based on scientific data available in literature, into the existing and validated Markkanen room model. A sensitivity analysis of the different parameters impacting the calculated absorbed dose rate in air is performed. For the different improvements implemented in the dosimetric evaluation the impact and practicality for industrial implementation is discussed.

\section{Materials \& Methods}

\subsection{Materials}


For the evaluation of the dose model the composition of concrete, defined by NIST [32], is used, except when mentioned differently.

\subsection{Model}

\section{$\underline{\text { 2.2.1 Model description }}$}

To assess the absorbed dose rate in air $\left(D_{A}\right)$, the room model of Markkanen [1] (see Equation 1 ) is used.

$$
D_{A}=5.77 \times 10^{-7} \frac{A C \rho}{4 \pi} \sum \gamma_{i}\left(\frac{\mu_{e n}}{\rho}\right)_{i} E_{i} \int B_{i} \frac{\mathrm{e}^{-\mu_{i} s}}{l^{2}} \mathrm{dV}
$$

With $D_{A}$ the absorbed dose rate in air in $\mathrm{Gy} / \mathrm{h}, A C$ the activity concentration of a radionuclide incorporated in the material of concern in $\mathrm{Bq} / \mathrm{kg}, \rho$ the density of the material in $\mathrm{kg} / \mathrm{m}^{3}, \nu_{i}$ the gamma intensity of gamma line $i,\left(\mu_{\mathrm{en}} / \rho\right)_{i}$ the energy absorption coefficient in air for gamma energy $E_{i}$ in $\mathrm{cm}^{2} / \mathrm{g}, E_{i}$ the photon energy in $\mathrm{MeV}, \mu_{i}$ the linear attenuation coefficient of the material for gamma energy $E_{i}$ in $\mathrm{cm}^{-1}, B_{i}$ the dose build up factor (see Equation 2) calculated via the Berger's formula, $l$ the distance between the point of detection $\left(x_{p}, y_{p}, z_{p}\right)$ and the point of integration in $\mathrm{cm}$ (see Equation 4) and $s$ the fraction of $l$ within the top layer in $\mathrm{cm}$ (see Equation 3). The total exposure rate is the sum of the exposure rates calculated from ceiling, floor and each wall. The $\left(\mu_{e n} / \rho\right)_{i}$ is a polynomial best fit achieved from the data reported by Martin [33] using the data of Hubbell and Seltzer [34].

$B_{i}=1+C\left(E_{i}\right) \mu_{i} s e^{D\left(E_{i}\right) \mu_{i} s}$

In literature different $C$ and $D$ parameters are proposed by different authors. In the model described here, the values of $C$ and $D$ proposed by Pelliccioni [35] are used. These are calculated for the energy spectrum via logarithmic and exponential best-fit function respectively by using the concrete parameters described by Pelliccioni [35] at 7 mean free paths (mfp).

$s=\left|\frac{z}{z_{p}-z}\right| l$

In order to convert the $D_{A}$ to effective dose a conversion factor of $0.7 \mathrm{~Sv} / \mathrm{Gy}$ is used [28]. This conversion factor is used for all gamma emitters and originates from the UNSCEAR 2000 report [3].-This conversion factor is used in the dose calculations considered in this article and is consequently used for comparison reasons. Nevertheless, nuclide specific conversion factors have been suggested by Krstic and Nikezic [36]. 
The model assumes a homogeneous sample composition and a homogeneous distribution of the radionuclides throughout the composed materials. In addition a standard room is used as a reference throughout the paper. The standard room size was described by Koblinger [15] as measuring $400 \mathrm{~cm} \times 500 \mathrm{~cm} \times 280 \mathrm{~cm}$. Here a standard thickness of walls, floor and ceiling of $20 \mathrm{~cm}$ is assumed. Neither doors nor windows are present and the point of detection $\left(x_{p}, y_{p}\right.$, $z_{p}$ ) is set at the middle of the room. Whereas Koblinger suggested a density of $2320 \mathrm{~kg} / \mathrm{m}^{3}, \mathrm{RP}-$ 112 suggests a density of $2350 \mathrm{~kg} / \mathrm{m}^{3}[15,28]$. The value of $2350 \mathrm{~kg} / \mathrm{m}^{3}$ is used here as a standard.

No background correction is assumed when calculating the $D_{A}$.

192

193

194

195

196

197

198

199

200

201

202

203

204

205

206

207

208

209

210

211

212

213

214

215

216

217

218

219

220

221

222

All calculations are performed by a combination of Microsoft ${ }^{\circledR}$ excel and $R^{\circledast}$ [37]. The input parameters are submitted in Microsoft ${ }^{\circledR}$ excel whereas the further treatment of the input data is performed by Microsoft ${ }^{\circledR}$ excel and $\mathrm{R}^{\circledR}$.

\subsubsection{Selection of the number of gamma lines}

In order to check the impact of the number of gamma lines, a comparison of the absorbed dose rate in air is made between different dose assessment models for a standard room. The Markkanen [1], Mustonen [22], ISS room model [23] and the model developed in this study, further called Expanded Gamma Dose Assessment (EGDA) model, are compared. Different versions of the EGDA model are evaluated depending on the number of gamma lines used for the dose assessment. 'EGDA $>1 \%$ ', 'EGDA $>0.1 \%$ ', 'EGDA $>0 \%$ ' take into account all gamma lines which have a gamma emission intensity (including the branching factor) above respectively 1 $\%, 0.1 \%$ and $0 \%$ when considering gamma emission lines from the ${ }^{238} \mathrm{U},{ }^{232} \mathrm{Th}$ and ${ }^{235} \mathrm{U}$ decay series and ${ }^{40} \mathrm{~K}$. In addition two variants of 'EGDA $>0.1 \%$ ' are discussed. In one variant the emission gamma lines of ${ }^{238} \mathrm{U}$ and ${ }^{232} \mathrm{Th}$ (except for the $2614 \mathrm{keV}$ gamma emission line since this emission line represents over $40 \%$ of the dose rate of the ${ }^{232} \mathrm{Th}$ decay series) of 'EGDA $>0.1 \%$ ' are converted to one weighted average gamma emission line. This variant is indicated in Table 1 by the suffix "averaged". In the second variant the emission gamma lines which have a gamma emission intensity lower than $0.1 \%$ are converted to one weighted average gamma line for ${ }^{238} \mathrm{U},{ }^{232} \mathrm{Th}$ and ${ }^{235} \mathrm{U}$. This variant is indicated in Table 1 as "EGDA+". Details on each model are provided in Table 1 . Since not all the details necessary for the calculations were present in the original paper of Markkanen [1] and Mustonen [22], updated values were used (details in Table 1). This is indicated by a suffix "updated". In addition, a second variant of the ISS room model, which makes use of the Berger parameters described by Pelliccioni [35] instead of the Berger parameters of Markkanen [1], is discussed. This variant is indicated with the infix "Pelliccioni" whereas the original ISS room model is indicated with the infix "original". For readability, abbreviations of the dose model names are provided in Table 1 and Table 5. 
223 Table 1: Overview of the different dose calculation models and their parameters used to 224 evaluate the absorbed dose rate in air.

\begin{tabular}{|c|c|c|c|c|c|c|c|c|c|c|}
\hline Model & $\begin{array}{c}\text { Markkanen } \\
\text { original }\end{array}$ & $\begin{array}{c}\text { Markkanen } \\
\text { updated }\end{array}$ & $\begin{array}{c}\text { Mustonen } \\
\text { updated }\end{array}$ & $\begin{array}{l}\text { ISS original } \\
\text { room } \\
\text { model }\end{array}$ & $\begin{array}{l}\text { ISS } \\
\text { Pelliccioni } \\
\text { room } \\
\text { model }\end{array}$ & EGDA $>1 \%$ & EGDA $>0.1 \%$ & $\begin{array}{c}\text { EGDA }>0.1 \% \\
\text { averaged }\end{array}$ & EGDA+ & $E G D A>0 \%$ \\
\hline $\begin{array}{c}\text { Concrete } \\
\text { composition }\end{array}$ & $\begin{array}{c}\text { Markkanen } \\
1995 \text { [1] }\end{array}$ & $\begin{array}{c}\text { Ordinary } \\
\text { Portland } \\
\text { concrete } \\
\text { (NIST) }\end{array}$ & $\begin{array}{c}\text { Ordinary } \\
\text { Portland } \\
\text { concrete } \\
\text { (NIST) }\end{array}$ & $\begin{array}{c}\text { Ordinary } \\
\text { Portland } \\
\text { concrete } \\
\text { (NIST) }\end{array}$ & $\begin{array}{c}\text { Ordinary } \\
\text { Portland } \\
\text { concrete } \\
\text { (NIST) }\end{array}$ & $\begin{array}{c}\text { Ordinary } \\
\text { Portland } \\
\text { concrete } \\
\text { (NIST) }\end{array}$ & $\begin{array}{c}\text { Ordinary } \\
\text { Portland } \\
\text { concrete } \\
\text { (NIST) }\end{array}$ & $\begin{array}{c}\text { Ordinary } \\
\text { Portland } \\
\text { concrete } \\
\text { (NIST) }\end{array}$ & $\begin{array}{c}\text { Ordinary } \\
\text { Portland } \\
\text { concrete } \\
\text { (NIST) }\end{array}$ & $\begin{array}{c}\text { Ordinary } \\
\text { Portland } \\
\text { concrete } \\
\text { (NIST) }\end{array}$ \\
\hline $\begin{array}{c}\text { Energy } \\
\text { absorption } \\
\text { coefficient } \\
\text { in air }\end{array}$ & $\begin{array}{c}\text { Markkanen } \\
1995 \text { [1] }\end{array}$ & $\begin{array}{l}\text { Best fit } \\
\text { from } \\
\text { Martin } \\
2006[33]\end{array}$ & $\begin{array}{l}\text { Best fit } \\
\text { from } \\
\text { Martin } \\
2006[33]\end{array}$ & $\begin{array}{l}\text { Hubbell } \\
1982[38]\end{array}$ & $\begin{array}{c}\text { Hubell } \\
1982[38]\end{array}$ & $\begin{array}{c}\text { Best fit } \\
\text { from } \\
\text { Martin } \\
2006[33]\end{array}$ & $\begin{array}{c}\text { Best fit } \\
\text { from Martin } \\
2006[33]\end{array}$ & $\begin{array}{c}\text { Best fit } \\
\text { from } \\
\text { Martin } \\
2006[33]\end{array}$ & $\begin{array}{l}\text { Best fit } \\
\text { from } \\
\text { Martin } \\
2006[33]\end{array}$ & $\begin{array}{c}\text { Best fit } \\
\text { from } \\
\text { Martin } \\
2006[33]\end{array}$ \\
\hline $\begin{array}{l}\text { Density } \\
\text { (kg/m3) }\end{array}$ & 2350 & 2350 & 2350 & 2350 & 2350 & 2350 & 2350 & 2350 & 2350 & 2350 \\
\hline $\begin{array}{l}\text { Linear } \\
\text { attenuation } \\
\text { coefficient }\end{array}$ & $\begin{array}{c}\text { From } \\
\text { Markkanen } \\
1995[1]\end{array}$ & $\begin{array}{l}\text { XCOM [39]: } \\
\text { ordinary } \\
\text { Portland } \\
\text { concrete } \\
\text { (NIST) }\end{array}$ & $\begin{array}{c}\text { XCOM } \\
\text { [39]: } \\
\text { ordinary } \\
\text { Portland } \\
\text { concrete } \\
\text { (NIST) }\end{array}$ & $\begin{array}{l}\text { Hubbell } \\
1982[38]\end{array}$ & $\begin{array}{l}\text { Hubbell } \\
1982[38]\end{array}$ & $\begin{array}{c}\text { XCOM } \\
\text { [39]: } \\
\text { ordinary } \\
\text { Portland } \\
\text { concrete } \\
\text { (NIST) or } \\
\text { IP }\end{array}$ & $\begin{array}{l}\text { XCOM [39]: } \\
\text { ordinary } \\
\text { Portland } \\
\text { concrete } \\
\text { (NIST) or IP }\end{array}$ & $\begin{array}{l}\text { XCOM [39]: } \\
\text { ordinary } \\
\text { Portland } \\
\text { concrete } \\
\text { (NIST) or IP }\end{array}$ & $\begin{array}{c}\text { XCOM } \\
\text { [39]: } \\
\text { ordinary } \\
\text { Portland } \\
\text { concrete } \\
\text { (NIST) or } \\
\text { IP }\end{array}$ & $\begin{array}{c}\text { XCOM } \\
\text { [39]: } \\
\text { ordinary } \\
\text { Portland } \\
\text { concrete } \\
\text { (NIST) or } \\
\text { IP }\end{array}$ \\
\hline $\begin{array}{c}\text { Gamma } \\
\text { emission } \\
\text { energy and } \\
\text { intensity }\end{array}$ & $\begin{array}{c}\text { Markkanen } \\
1995 \text { [1] }\end{array}$ & $\begin{array}{c}\text { Mustonen } \\
1984 \text { [22] }\end{array}$ & $\begin{array}{c}\text { Mustonen } \\
1984 \text { [22] }\end{array}$ & $\begin{array}{c}\text { NuDat } \\
\text { website } \\
\text { [40] }\end{array}$ & $\begin{array}{c}\text { NuDat } \\
\text { website } \\
\text { [40] }\end{array}$ & $\begin{array}{c}\text { DDEP } \\
\text { website } \\
\text { [31] }\end{array}$ & $\begin{array}{c}\text { DDEP } \\
\text { website [31] }\end{array}$ & $\begin{array}{c}\text { DDEP } \\
\text { website } \\
\text { [31] }\end{array}$ & $\begin{array}{c}\text { DDEP } \\
\text { website } \\
\text { [31] }\end{array}$ & $\begin{array}{c}\text { DDEP } \\
\text { website } \\
\text { [31] }\end{array}$ \\
\hline $\begin{array}{c}\text { Berger } \\
\text { Parameters }\end{array}$ & $\begin{array}{c}\text { Markkanen } \\
1995[1]\end{array}$ & $\begin{array}{l}\text { Best fit of } \\
\text { Pelliccioni } \\
1989 \text { [35] }\end{array}$ & $\begin{array}{l}\text { Best fit of } \\
\text { Pelliccioni } \\
1989 \text { [35] }\end{array}$ & $\begin{array}{c}\text { Best fit of } \\
\text { Markkanen } \\
1995[1]\end{array}$ & $\begin{array}{l}\text { Best fit of } \\
\text { Pelliccioni } \\
1989 \text { [35] }\end{array}$ & $\begin{array}{l}\text { Best fit of } \\
\text { Pelliccioni } \\
1989 \text { [35] }\end{array}$ & $\begin{array}{l}\text { Best fit of } \\
\text { Pelliccioni } \\
1989 \text { [35] }\end{array}$ & $\begin{array}{l}\text { Best fit of } \\
\text { Pelliccioni } \\
1989 \text { [35] }\end{array}$ & $\begin{array}{l}\text { Best fit of } \\
\text { Pelliccioni } \\
1989 \text { [35] }\end{array}$ & $\begin{array}{l}\text { Best fit of } \\
\text { Pelliccioni } \\
1989 \text { [35] }\end{array}$ \\
\hline $\begin{array}{c}\text { Number of } \\
\text { gamma lines } \\
{ }^{238} U\end{array}$ & 1 & 1 & 24 & $19 *$ & $19 *$ & 82 & 87 & $1^{*}$ & $87+1^{* *}$ & 761 \\
\hline $\begin{array}{c}\text { Gamma } \\
\text { emission } \\
\text { intensity } \\
238 U^{* * *}\end{array}$ & 2.12 & 2.12 & 2.12 & 2.41 & 2.41 & 2.19 & 2.36 & 2.36 & 2.41 & 2.41 \\
\hline $\begin{array}{l}\text { Number of } \\
\text { gamma lines } \\
{ }^{232} \mathrm{Th}\end{array}$ & 2 & 2 & 20 & $14^{*}$ & $14^{*}$ & 36 & 110 & 2* & $110+1^{* *}$ & 349 \\
\hline
\end{tabular}




\begin{tabular}{|c|c|c|c|c|c|c|c|c|c|c|}
\hline $\begin{array}{l}\text { Gamma } \\
\text { emission } \\
\text { intensity } \\
{ }^{232} \mathrm{Th}^{* * *}\end{array}$ & 2.41 & 2.41 & 2.41 & 2.63 & 2.63 & 2.76 & 2.98 & 2.98 & 3.04 & 3.04 \\
\hline $\begin{array}{c}\text { Number of } \\
\text { gamma lines } \\
{ }^{40} \mathrm{~K}\end{array}$ & 1 & 1 & 1 & 1 & 1 & 1 & 1 & 1 & 1 & 1 \\
\hline $\begin{array}{c}\text { Gamma } \\
\text { emission } \\
\text { intensity }{ }^{40} \mathrm{~K}\end{array}$ & 0.107 & 0.107 & 0.107 & 0.107 & 0.107 & 0.1055 & 0.1055 & 0.1055 & 0.1055 & 0.1055 \\
\hline $\begin{array}{c}\text { Number of } \\
\text { gamma lines } \\
{ }^{235} \mathrm{U}\end{array}$ & - & - & - & - & - & 47 & 128 & $1^{*}$ & $128+1 * *$ & 734 \\
\hline $\begin{array}{c}\text { Gamma } \\
\text { emission } \\
\text { intensity } \\
{ }^{235} \mathrm{U}^{* * *}\end{array}$ & - & - & - & - & - & 2.78 & 3.04 & 3.04 & 3.1 & 3.1 \\
\hline $\begin{array}{c}\text { Model } \\
\text { abbreviation }\end{array}$ & Mark $_{\text {orig }}$ & Markupd & Mustupd & ISS orig & ISS Pelli & - & - & - & - & - \\
\hline
\end{tabular}

* 87, 109 and 128 gamma emission lines are converted to 1 for respectively ${ }^{238} \mathrm{U},{ }^{232} \mathrm{Th}$ and ${ }^{235} \mathrm{U}$

** 674, 239 and 606 gamma emission lines are converted to 1 for respectively ${ }^{238} \mathrm{U},{ }^{232} \mathrm{Th}$ and ${ }^{235} \mathrm{U}$

*** The gamma emission intensity is the sum of the individual gamma-ray emission energies.

\subsubsection{Role of the build-up factor}

The impact of the build-up factor (B) was evaluated for a standard room by using different sets of Berger parameters $C$ and $D$ to calculate the $D_{A}$ per unit of activity concentration. The Berger parameters as described by Markkanen and by Pelliccioni were compared $[1,35]$. In addition the case without Berger parameters $(C=D=0)$ is evaluated, meaning the role of buildup factor is neglected. The latter case is indicated by the suffix " $B=1$ " in Table 4 .

\subsubsection{Role of the presence disequilibria in the ${ }^{232} \mathrm{Th},{ }^{238} \mathrm{U}$ and ${ }^{235} \mathrm{U}$ decay series}

For model 'EGDA>0.1\%' the contribution of long living radionuclides and their progeny to the total absorbed dose rate in air per unit of activity concentration for the decay series of ${ }^{238} \mathrm{U}$ and ${ }^{232} \mathrm{Th}$ is evaluated. The ${ }^{238} \mathrm{U}$ decay chain is divided into 3 subchains : i.e. ${ }^{238} \mathrm{U}$-part ${ }^{238} \mathrm{U}$ to $\left.{ }^{230} \mathrm{Th}\right),{ }^{226} \mathrm{Ra}$-part $\left({ }^{226} \mathrm{Ra}\right.$ to $\left.{ }^{214} \mathrm{Po}\right)$ and ${ }^{210} \mathrm{~Pb}$-part $\left({ }^{210} \mathrm{~Pb}\right.$ to $\left.{ }^{210} \mathrm{Po}\right)$. Similar, the ${ }^{232} \mathrm{Th}$ decay chain is divided into ${ }^{232} \mathrm{Th}$-part (only ${ }^{232} \mathrm{Th}$ ), ${ }^{228} \mathrm{Ra}$-part $\left({ }^{228} \mathrm{Ra}\right.$ to ${ }^{228} \mathrm{Ac}$ ) and ${ }^{228} \mathrm{Th}$-part $\left({ }^{228} \mathrm{Th}\right.$ to $\left.{ }^{208} \mathrm{TI}\right)$. The absorbed dose rate in air of ${ }^{235} \mathrm{U}$ is evaluated in the framework of the ratio of $\mathrm{AC}$ of ${ }^{238} \mathrm{U} /{ }^{235} \mathrm{U}$ i.e. 21.6 as expected value for non- diluted/enriched samples. No disequilibrium is 
considered in case of ${ }^{235} \mathrm{U}$ decay series as (dis)equilibrium in this decay series is often not reported.

\subsubsection{Impact of sample specific composition}

The impact of the sample composition on the dose rate is compared by simulating a room constructed out of Fayalite Slag based Inorganic Polymers (FSIPs). FSIPs have different chemical, physical and structural properties than concrete. The characteristics of FSIPs are described by Kriskova et al. [41], Onisei et al. [42] and lacobescu et al. [43]. The sample composition differs from concrete consequently leading to the usage of different linear attenuation coefficients. The attenuation coefficients are calculated for each gamma emission energy via the XCOM program [44]. The sample specific coherent mass attenuation coefficient of XCOM is therefore converted to the sample specific linear attenuation coefficient.

\subsection{Sensitivity Analysis}

A sensitivity analysis of the parameters impacting the absorbed dose rate in air is performed. The studied parameters are density, wall thickness, presence of windows and doors and room size. All parameters are compared to the standard parameters of a standard concrete room as defined in section 2.2.1.

\subsubsection{Density}

The impact of the wall density on the $D_{A}$ is tested for a standard room with density varying stepwise (step size of $100 \mathrm{~kg} / \mathrm{m}^{3}$ ) between $1000 \mathrm{~kg} / \mathrm{m}^{3}$ and $3500 \mathrm{~kg} / \mathrm{m}^{3}$, corresponding to the density of hollow bricks up to the density of high density concrete.

\subsubsection{Wall Thickness}

In a standard concrete room the wall thickness is assumed to be $20 \mathrm{~cm}$. However depending on the usage thinner or thicker walls are required. The impact of the wall thickness on the $D_{A}$ in the standard room is tested with wall thickness varying stepwise (step size of $5 \mathrm{~cm}$ ) between $5 \mathrm{~cm}$ and $80 \mathrm{~cm}$ while keeping floor and ceiling thickness constant at $20 \mathrm{~cm}$.

\subsubsection{Room Size}

The impact of the room size on the $D_{A}$ is tested for a concrete room. A square room is simulated with length of the wall varying stepwise (step size of $100 \mathrm{~cm}$ ) between $100 \mathrm{~cm}$ and $1000 \mathrm{~cm}$ for a room height of $280 \mathrm{~cm}$ and between $100 \mathrm{~cm}$ and $1183.2 \mathrm{~cm}$ for a room height of $200 \mathrm{~cm}$.

\section{$\underline{\text { 2.3.4 Presence of windows and doors }}$}

The EU-BSS assumes a standard room without the presence of windows and doors. This is a strict approach but not realistic. The impact of the presence of windows or doors of different surfaces is tested. Tests are conducted for surfaces of $1 \mathrm{~m}^{2}, 2 \mathrm{~m}^{2}$ and $4 \mathrm{~m}^{2}$ positioned in the 
middle or the corner of a wall or ceiling. The imaginary dose rate originating of the specific window/door surface is subtracted from the dose rate of the wall without any window/door.

\subsection{Comparison of index and dose assessment tools}

A comparison is made of the most used index and dose calculations relevant for the dose assessment within the European legislative framework applicable towards building materials. More details regarding these different index and dose calculations are shown in Table 2 or can be found in the respective references.

The index values calculated via $\mathrm{ACl}$ and the density and thickness corrected index $(\mathrm{I}(\rho \mathrm{d}))$ are compared using the $A C$ of different types of residues and cement shown in Table $3[1,2,4]$. The obtained dose of the Markkanen original, density and thickness corrected $(D(\rho d))$ and EGDA $>0 \%$ dose calculations are compared using the same $A C[1,2,30]$. In addition to the standard density of $2350 \mathrm{~kg} / \mathrm{m}^{3}$ and standard thickness of $20 \mathrm{~cm}$, six different scenarios are tested with varying density and thickness (Table 4). In the comparisons, it is assumed that the residues are solely used to construct a building material, this because recent studies $[45,46]$ indicate the applicability of building materials without the use of any additives like cement, sand, gravel, etc. The AC values originate from Nuccetelli et al. [10]. In all cases the exposure time is $7000 \mathrm{~h}$.

Table 2: Overview of the parameters of the index and dose calculations used in the European legislative framework applicable towards building materials.

\begin{tabular}{|c|c|c|c|c|c|}
\hline & \multicolumn{2}{|c|}{ Index calculation } & \multicolumn{3}{|c|}{ Dose calculation } \\
\hline & $\mathrm{ACl}$ & $I(\rho d)$ & $\begin{array}{c}\text { Markkanen } \\
\text { original }\end{array}$ & $D(\rho d)$ & $E G D A>0 \%$ \\
\hline Geometry & $\begin{array}{l}\text { Floor, ceiling, } \\
4 \text { walls }\end{array}$ & $\begin{array}{l}\text { Floor, } \\
\text { ceiling, } 4 \\
\text { walls }\end{array}$ & $\begin{array}{l}\text { Floor, ceiling, } \\
4 \text { walls }\end{array}$ & $\begin{array}{l}\text { Floor, } \\
\text { ceiling, } 4 \\
\text { walls }\end{array}$ & $\begin{array}{l}\text { Floor, } \\
\text { ceiling, } 4 \\
\text { walls }\end{array}$ \\
\hline $\begin{array}{l}\text { Size geometry } \\
\left(\mathrm{cm}^{3}\right)\end{array}$ & $\begin{array}{c}400 \times 500 \times \\
280^{*}\end{array}$ & $\begin{array}{c}400 \times 500 \times \\
280\end{array}$ & $\begin{array}{c}400 \times 500 x \\
280\end{array}$ & $\begin{array}{c}400 \times 500 x \\
280\end{array}$ & $\begin{array}{c}\text { (Flexible) } \\
\text { Here } 400 \times \\
500 \times 280\end{array}$ \\
\hline $\begin{array}{l}\text { Wall thickness } \\
(\mathrm{cm})\end{array}$ & 20 & Flexible & 20 & Flexible & Flexible \\
\hline Density $\left(\mathrm{kg} / \mathrm{m}^{3}\right)$ & $2350 * *$ & Flexible & $2350 * *$ & Flexible & Flexible \\
\hline $\begin{array}{l}\text { Background } \\
\text { correction }\end{array}$ & 70 nGy/h & $50 \mathrm{nGy} / \mathrm{h}$ & $0.348 \mathrm{mSv}$ & $0.245 \mathrm{mSv}$ & $0.245 \mathrm{mSv}$ \\
\hline
\end{tabular}




\begin{tabular}{|c|c|c|c|c|c|}
\hline Composition & Concrete & Concrete & Concrete & Concrete & $\begin{array}{c}\text { (Flexible) } \\
\text { Here } \\
\text { Concrete }\end{array}$ \\
\hline Reference(s) & $\begin{array}{l}\text { EC 2014; } \\
\text { RP112; } \\
\text { Markkanen } \\
1995\end{array}$ & $\begin{array}{l}\text { Nucetelli et } \\
\text { al. } 2015\end{array}$ & $\begin{array}{c}\text { EC 2014; } \\
\text { RP112; } \\
\text { Markkanen } \\
1995\end{array}$ & $\begin{array}{l}\text { Nucetelli et } \\
\text { al. } 2015\end{array}$ & \\
\hline
\end{tabular}

* In Markkanen 1995 size is $12 \times 7 \times 2.8 \mathrm{~m}^{3}$ with thickness of $0.2 \mathrm{~m}$

** In Markkanen 1995 density is $2320 \mathrm{~kg} / \mathrm{m}^{3}$

312

313

315

316

317

318

319

320

321

322

323

324

325

326

327

328

329

330

331

332

333

334

335

Table 3: Activity concentrations (Bq/ $\mathrm{kg}$ ) of ${ }^{226} \mathrm{Ra},{ }^{232} \mathrm{Th}$ and ${ }^{40} \mathrm{~K}$ present in different residues and cement.

\begin{tabular}{|l|ccc|l|}
\hline \multicolumn{1}{|c|}{ Material type } & $\begin{array}{c}\mathbf{2 2 6}^{2} \mathbf{R a} \\
\mathbf{( B q} / \mathbf{k g})\end{array}$ & $\begin{array}{c}\mathbf{2 3 2}^{\mathbf{T h}} \\
\mathbf{( B q} / \mathbf{k g})\end{array}$ & $\begin{array}{c}\mathbf{4 0}^{\mathbf{K}} \\
\mathbf{( B q} / \mathbf{k g})\end{array}$ & Reference \\
\hline Furnace slags * & 147 & 42 & 258 & Nuccetelli et al. 2015 \\
Bottom ash and fly ash * & 207 & 80 & 546 & Nuccetelli et al. 2015 \\
Phosphogypsum * & 381 & 22 & 71 & Nuccetelli et al. 2015 \\
Bauxite residue * & 337 & 480 & 205 & Nuccetelli et al. 2015 \\
Cement * & 42 & 32 & 214 & Nuccetelli et al. 2015 \\
\hline
\end{tabular}

* Average values of database from Nuccetelli et al. 2015 [10]

Table 4: Description of 6 different scenarios which are described by a specific set of density and thickness. The scenarios are used for the comparison of the models of Table 2.

\begin{tabular}{|l|cccccc|}
\hline Scenario number & 1 & 2 & 3 & 4 & 5 & 6 \\
\hline Thickness $(\mathbf{c m})$ & 10 & 10 & 18 & 25 & 40 & 40 \\
\hline Density $\left(\mathbf{k g} / \mathbf{m}^{3}\right)$ & 1400 & 3000 & 3000 & 1400 & 1400 & 3000 \\
\hline
\end{tabular}

\section{Results and discussion}

In section 3.1 the different absorbed dose rates in air per unit of activity concentration for ${ }^{238} \mathrm{U},{ }^{232} \mathrm{Th},{ }^{40} \mathrm{~K}$ and ${ }^{235} \mathrm{U}$ obtained by different dose assessment models are compared. This section discusses the impact of working with averaged gamma emission lines as well as the impact of the build-up factor and the radiological equilibria.

Based on this comparison, the most practical EGDA model with the highest gamma emission intensity is selected and in section 3.2 a sensitivity analysis of this model is performed by changing wall thickness and density, room size and the presence of windows and doors. Throughout section 3.1 and 3.2 the impact of the sample composition is quantified.

Section 3.3 deals with the application of the model focussing on the dosimetric evaluation, the impact and the practicality for industrial implementation. Consequently a comparison is 
performed of the most used index and dose calculations relevant for the dose assessment within the European legislative framework applicable towards building materials.

\subsection{Model}

\subsubsection{Impact of the number of gamma lines}

Table 5 shows the $D_{A}$ per unit of activity concentration for ${ }^{238} \mathrm{U},{ }^{232} \mathrm{Th},{ }^{40} \mathrm{~K}$ and ${ }^{235} \mathrm{U}$ of the different models described in Table 1 . The different models assume a concrete standard room unless indicated else by suffix FSIP.

Table 5: Overview of the absorbed dose rate in air per unit of activity concentration ( $\mathrm{nGy} / \mathrm{h}$ per $\mathrm{Bq} / \mathrm{kg}$ ) for ${ }^{238} \mathrm{U},{ }^{232} \mathrm{Th},{ }^{40} \mathrm{~K}$ and ${ }^{235} \mathrm{U}$ calculated by different dose assessment calculation models described in Table 1.

\begin{tabular}{|c|c|c|c|c|}
\hline & ${ }^{238} \mathrm{U}$ & ${ }^{232} \mathrm{Th}$ & ${ }^{40} K$ & ${ }^{235} \mathrm{U}$ \\
\hline Model abbreviation & $\begin{array}{c}\text { Dose rate in } \\
\text { air }\left(D_{A}\right) \\
(n G y / h \text { per } \\
\mathrm{Bq} / \mathrm{kg})\end{array}$ & $\begin{array}{c}\text { Dose rate in } \\
\text { air }\left(D_{A}\right) \\
(n G y / h \text { per } \\
\mathrm{Bq} / \mathrm{kg})\end{array}$ & $\begin{array}{c}\text { Dose rate in } \\
\text { air }\left(D_{A}\right) \\
(\mathrm{nGy} / \mathrm{h} \text { per } \\
\mathrm{Bq} / \mathrm{kg} \text { ) }\end{array}$ & $\begin{array}{c}\text { Dose rate in } \\
\text { air }\left(D_{A}\right) \\
\text { (nGy/h per } \\
B q / k g)\end{array}$ \\
\hline Mark orig & 0.908 & 1.06 & 0.0767 & - \\
\hline Mark $_{\text {orig } B=1}$ & 0.3845 & 0.5 & 0.0408 & - \\
\hline Mark upd & 0.893 & 1.02 & 0.0778 & - \\
\hline Mark $_{\text {upd B }}=1$ & 0.383 & 0.501 & 0.0407 & - \\
\hline Must $_{\text {upd }}$ & 0.84 & 0.999 & 0.0778 & - \\
\hline Must $_{\text {upd } B=1}$ & 0.0405 & 0.51 & 0.0407 & - \\
\hline ISS $_{\text {orig }}$ & 0.894 & 1.138 & 0.0767 & - \\
\hline ISS Pelli $_{1}$ & 0.869 & 1.109 & 0.0767 & - \\
\hline$E G D A>1 \%$ & 0.76 & 0.967 & 0.0767 & 0.228 \\
\hline$E G D A>0.1 \%$ & 0.826 & 1.06 & 0.0767 & 0.25 \\
\hline $\mathrm{EGDA}>0.1 \%_{\mathrm{B}=1}$ & 0.395 & 0.535 & 0.0401 & 0.0819 \\
\hline$E G D A>0.1 \% \mathrm{FSIP}$ & 0.838 & 1.07 & 0.0784 & 0.234 \\
\hline EGDA $>0.1 \%$ aver & 0.88 & 1.07 & 0.0767 & 0.239 \\
\hline EGDA $>0.1 \%$ aver $B=1$ & 0.368 & 0.51 & 0.0401 & 0.0725 \\
\hline EGDA+ & 0.85 & 1.08 & 0.0767 & 0.255 \\
\hline $\mathrm{EGDA}>0 \%$ & 0.849 & 1.08 & 0.0767 & 0.256 \\
\hline
\end{tabular}

Suffix 'orig' (original): Data of the original paper are used as shown in Table 2.

Suffix 'upd' (updated): Updated data, as shown in Table 2, are used with the original calculation method. Suffix ' $B=1$ ' (build-up factor =1): The Berger parameters are set to zero. This means the role of the build-up factor is negligible.

Suffix 'aver' (averaged): Several gamma lines are reduced to a single weighted average gamma emission line. Suffix 'Pelli' (Pelliccioni): the Berger parameters as described by Pelliccioni 1989 are used. FSIP: The chemical composition of the room components is set to the FSIP chemical composition. 


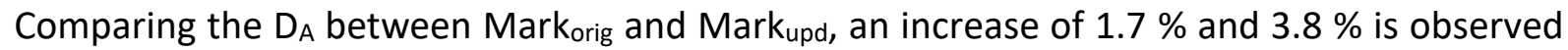
for respectively ${ }^{238} \mathrm{U}$ and ${ }^{232} \mathrm{Th}$, in favour of the Mark orig model. In case of ${ }^{40} \mathrm{~K}$ a decrease of 1.4 $\%$ is observed in favour of the Markorig model. This deviation in $D_{A}$ is due to the usage of different Berger parameters and a different concrete composition in the two models (Table 1).

The 24 emission gamma lines of ${ }^{238} \mathrm{U}$ and the 19 gamma emission lines (2614 keV-line is excluded) of ${ }^{232} \mathrm{Th}$ of the Mustonen model are converted to a single weighted average gamma emission line for ${ }^{238} \mathrm{U}$ and ${ }^{232} \mathrm{Th}$ in the Markkanen model.

Comparing Markupd with Must ${ }_{u p d}$ a $6 \%$ and $2 \%$ increase in $D_{A}$ is observed for respectively ${ }^{238} \mathrm{U}$ and ${ }^{232} \mathrm{Th}$. This increase is solely due to usage of averaged gamma lines in the Markkanen model. In case of ${ }^{235} \mathrm{U}$ a decrease in the $\mathrm{D}_{A}$ of $4.6 \%$ (4.9\%) is observed for the 'averaged EGDA' variant. The differences are solely due to the usage of energy specific attenuation coefficients and energy specific $C$ and $D$ Berger parameters as the total gamma intensity stays equal.

When comparing the EGDA models with Mark upd, $_{\text {Must }}$ upd $_{\text {and }}$ the ISS room models one can see that the number of gamma lines used is much higher (Table 1). When more gamma lines are included in the EGDA model the gamma emission intensity also increases for ${ }^{238} \mathrm{U},{ }^{232} \mathrm{Th}$ and ${ }^{235} \mathrm{U}$, leading to higher $\mathrm{D}_{A}$ when comparing $E G D A>1 \%, E G D A>0.1 \%$ and $E G D A>0 \%$. However the gamma emission intensity of the ISS room model is smaller than the gamma emission intensity of EGDA $>0 \%$ for ${ }^{238} \mathrm{U}$ and ${ }^{232} \mathrm{Th}$ (Table 1 ), still the $\mathrm{D}_{\mathrm{A}}$ of the ISS room model is higher than the $D_{A}$ of EGDA $>0 \%$ (Table 5). The usage of a set of averaged gamma-lines in the ISS room models tends to increase the $D_{A}$, as discussed above. In addition the usage of other

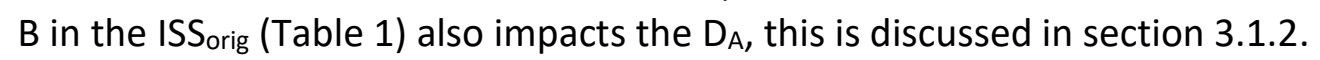

The EGDA>0\% model uses all the gamma lines available originating from ${ }^{238} \mathrm{U},{ }^{232} \mathrm{Th},{ }^{235} \mathrm{U}$ and ${ }^{40} \mathrm{~K}$. In total 1845 gamma lines are used in the calculation by model EGDA $>0 \%$ whereas in model EGDA $>0.1 \% 326$ gamma lines are used. The gamma emission intensity of EGDA $>0.1 \%$ is $2.1 \%, 2.0 \%$ and $1.9 \%$ lower than EGDA>0\% for respectively ${ }^{238} \mathrm{U},{ }^{232} \mathrm{Th}$ and ${ }^{235} \mathrm{U}$. Nevertheless, when using a higher number of gamma lines also the calculation time increases. In order to limit the calculation but still consider the maximum gamma emission intensity, the extra gamma lines of EGDA $>0 \%$ in comparison to EGDA $>0.1 \%$ are converted to 3 weighted average gamma lines; one line for ${ }^{238} \mathrm{U},{ }^{232} \mathrm{Th}$ and ${ }^{235} \mathrm{U}$. This approach is incorporated in the EGDA+ model (Table 1). The difference in $\mathrm{D}_{\mathrm{A}}$ between EGDA+ and EGDA $>0 \%$ is limited to plus $0.001 \mathrm{nGy} / \mathrm{h}$ per $\mathrm{Bq} / \mathrm{kg}$ for ${ }^{238} \mathrm{U}$ and minus $0.001 \mathrm{nGy} / \mathrm{h}$ per $\mathrm{Bq} / \mathrm{kg}$ for ${ }^{235} \mathrm{U}$. In case of ${ }^{232} \mathrm{Th}$ no difference was observed.

\subsubsection{Impact of the Build-up factor}

Table 5 shows the $D_{A}$ for several models. Comparing the $D_{A}$ of the " $B=1$ " variants with the nonunity originals, a significant decreases in the $D_{A}$ is present. For example in the case of EGDA>0.1\% the " $\mathrm{B}=1$ " variant has an $\mathrm{D}_{\mathrm{A}}$ which is approximately $52 \%, 50 \%, 48 \%$ and $67 \%$ lower for respectively ${ }^{238} \mathrm{U},{ }^{232} \mathrm{Th},{ }^{40} \mathrm{~K}$ and ${ }^{235} \mathrm{U}$. The presence of the $\mathrm{B}$ is consequently important when calculating the $D_{A}$. The ISS Pelli model differs only from the ISS orig model by the usage of the data of Pelliccioni instead of the data of Markkanen to calculate the B. Comparing both models, the $D_{A}$ per unit of activity concentration of the ISS Pelli model is $2.8 \%$ and $2.6 \%$ lower for respectively ${ }^{238} \mathrm{U}$ and ${ }^{232} \mathrm{Th}$ in case of a standard concrete room. 
Table 6: Absorbed dose rate in air $\left(D_{A}\right)$ per unit of activity concentration ( $\mathrm{nGy} / \mathrm{h}$ per $\mathrm{Bq} / \mathrm{kg}$ ) of the long-living radionuclides and their progeny of the ${ }^{238} \mathrm{U}$ and ${ }^{232} \mathrm{Th}$ decay series in case of the EGDA $>0.1 \%$ model.

\begin{tabular}{|c|c|c|c|c|c|}
\hline \multicolumn{6}{|c|}{ Concrete standard room } \\
\hline \multicolumn{3}{|c|}{${ }^{238} \mathrm{U}$ Decay series } & \multicolumn{3}{|c|}{${ }^{232}$ Th Decay series } \\
\hline & $\begin{array}{c}D_{A}(n G y / h \text { per } \\
B q / k g)\end{array}$ & $\begin{array}{c}\% \\
\text { Contribution }\end{array}$ & & $\begin{array}{c}D_{A}(n G y / h \text { per } \\
B q / k g)\end{array}$ & $\begin{array}{c}\% \\
\text { Contribution }\end{array}$ \\
\hline${ }^{238} \mathrm{U}$ Part & 0.0077 & 0.931 & ${ }^{232}$ Th Part & 0.000041 & 0.004 \\
\hline${ }^{226}$ Ra Part & 0.82 & 99.002 & ${ }^{228}$ Ra Part & 0.42 & 39.583 \\
\hline${ }^{210} \mathrm{~Pb}$ Part & 0.00055 & 0.067 & ${ }^{228}$ Th Part & 0.64 & 60.413 \\
\hline
\end{tabular}

Considering the decay series of ${ }^{238} \mathrm{U}$ : the ${ }^{238} \mathrm{U}$-part, ${ }^{226} \mathrm{Ra}$-part and ${ }^{210} \mathrm{~Pb}$-part of the decay chain represent respectively approximately $0.93 \%, 99 \%$ and $0.067 \%$ of the total external absorbed gamma dose rate in air per unit of activity concentration of the whole ${ }^{238} \mathrm{U}$ decay series, in the case of a standard concrete room. The lifespan of a building material will not allow reestablishing the equilibrium between the ${ }^{238} \mathrm{U}$-part and ${ }^{226} \mathrm{Ra}$-part. Looking solely at the lifespan aspect, it would be meaningful to treat both parts of the decay chain separately. However, this is not always feasible since one must be able to measure ${ }^{238} \mathrm{U},{ }^{234} \mathrm{Th}$ or ${ }^{234} \mathrm{~Pa}$. Using in this case the AC of ${ }^{226} \mathrm{Ra}$ for the whole decay series will only introduce a small bias since ${ }^{238} \mathrm{U}$ part and ${ }^{210} \mathrm{~Pb}$ contribute less than $1 \%$ to the total $\mathrm{D}_{\mathrm{A}}$ of the ${ }^{238} \mathrm{U}$ decay series. On the other hand using the $A C$ of ${ }^{238} \mathrm{U}$ for ${ }^{226} \mathrm{Ra}$ and its decay products would have a large impact as ${ }^{226} \mathrm{Ra}$-part represents $99 \%$ of the $D_{A}$ of the ${ }^{238} \mathrm{U}$ decay series. The suggestion of RP-122 to use the highest $A C$ present in the decay series would overestimate the gamma dose rate when the $A C$ of ${ }^{238} \mathrm{U}$ or ${ }^{210} \mathrm{~Pb}$ is larger than the $A C$ of ${ }^{226} \mathrm{Ra}$. Due to the small contribution of ${ }^{210} \mathrm{~Pb}$ part to the gamma dose (i.e. $0.067 \%$ ), the activity concentration of ${ }^{226} \mathrm{Ra}$ is used for the ${ }^{210} \mathrm{~Pb}$ part of the decay series in this study. The half-life of ${ }^{222} \mathrm{Rn}$ allows radon exhalation from the building material which decreases the external absorbed gamma dose rate in air. De Jong and Van Dijck (2008) [18] showed that the external absorbed gamma dose rate in air decreased on average with $9 \%$ and $5 \%$ for respectively gypsum and concrete used in the Netherlands. In addition the EU-BSS [4] treats the radon exposure (from soil and building materials) separately from the gamma exposure linked to building materials. For this reason all the EGDA models do not consider radon and is therefore stricter in terms of gamma ray exposure. chain represent respectively approximately $0.004 \%, 39.6 \%$ and $60.4 \%$ (Table 6) of the total external absorbed gamma dose rate in air per unit of activity concentration of the whole ${ }^{232} \mathrm{Th}$ decay series in the case of a standard concrete room. Disequilibria in the ${ }^{232} \mathrm{Th}$ decay chain are complex and insights in the production process of NORM-residues can provide useful information. In the case of complete Th-separation, the equilibrium will install within a timeframe of 40 years in the Th-bearing residue. Whereas in the Ra-bearing residue the activity will fade away. The lifetime of building materials can be considered to cover this timespan. Being strict, it is best not to consider disequilibrium and consider the highest activity concentration that is possible and use for the complete (so $100 \%$ ) $\mathrm{D}_{\mathrm{A}}$ calculation of the ${ }^{232} \mathrm{Th}$ 
decay series. An adequate determination of the activity concentration is recommended to assess whether or not disequilibria are present. In addition it is assumed in this study that no ${ }^{220} \mathrm{Rn}$ exhalation from the building material takes place as the half-life of ${ }^{220} \mathrm{Rn}$ is relatively short $(55.8 \mathrm{sec})$.

To the authors knowledge in none of current dose assessments tools available, the decay series of ${ }^{235} \mathrm{U}$ is considered. However taking into account all the gamma emission intensities above $0.1 \%$ the absorbed dose rate in air is $0.250 \mathrm{nGy} / \mathrm{h}$ per $\mathrm{Bq} / \mathrm{kg}$ for a standard concrete room (Table 5). This is above the $D_{A}$ of ${ }^{40} \mathrm{~K}$ on a $\mathrm{Bq} / \mathrm{kg}$ level. However framing this ${ }^{235} \cup \mathrm{D}_{\mathrm{A}}$ in a broader context, when the natural abundance of $U$ is respected the $A C$ of ${ }^{235} U$ is 0.0463 times the $A C$ of ${ }^{238} \mathrm{U}$. So in reality the contribution of the $D_{A}$ of ${ }^{235} \mathrm{U}$ is of limited consequence, except when high activity concentrations of ${ }^{238} \mathrm{U}$ are present. When no ${ }^{235} \mathrm{U}$ is measured, the authors recommend using 0.0463 times the $A C$ of ${ }^{238} \mathrm{U}$ to implement the dose originating from ${ }^{235} \mathrm{U}$. Within the ${ }^{235} \mathrm{U}$ decay series, disequilibrium situations can also be present but these are not considered here.

\subsubsection{Impact of sample specific composition}

The impact of the sample composition is studied by comparing EGDA $>0.1 \%$ and EGDA $>0.1 \%$ FSIP. An increase in the $D_{A}$ of $1.4 \%, 0.9 \%$ and $2.1 \%$ is observed for ${ }^{238} \mathrm{U},{ }^{232} \mathrm{Th}$ and ${ }^{40} \mathrm{~K}$ when FSIP is used instead of concrete. On the contrary, in case of ${ }^{235} \mathrm{U}$, a decrease in the $\mathrm{D}_{A}$ of $6.8 \%$ is observed. It has to be noted that here solely the linear attenuation coefficients are changed. A change of sample composition implies also changing the energy and $\mathrm{mfp}$-dependent $\mathrm{B}$, due to the interdependency between the composition, the energy and the mfp. However, the study of this aspect is outside the scope of this paper.

\subsubsection{Selection of EGDA $>0 \%$ model}

The EGDA $>0 \%$ model uses the highest gamma emission intensity and makes use of all the nuclear data on an individual base. Consequently this approach is the more accurate one and is selected for the performance of a sensitivity analysis in section 3.2. The use of 3 ighted gamma emission lines in case of ${ }^{238} \mathrm{U},{ }^{232} \mathrm{Th}$ and ${ }^{235} \mathrm{U}$, corresponding to respectively $2.1 \%, 2.0$ \% and $1.9 \%$ of the total gamma emission intensity, allows performing faster calculations in comparison to EGDA>0\% model. The $C$ and $D$ Berger parameters described by Pelliccioni (1989) [35] are used for the calculations.

The presence of gamma emission by ${ }^{235} \mathrm{U}$ is considered and disequilibrium situations can be considered when necessary.

\subsection{Sensitivity Analysis of EGDA $>0 \%$ Model}

3.2.1. Impact of the wall thickness calculated by the EGDA $>0 \%$ model. 


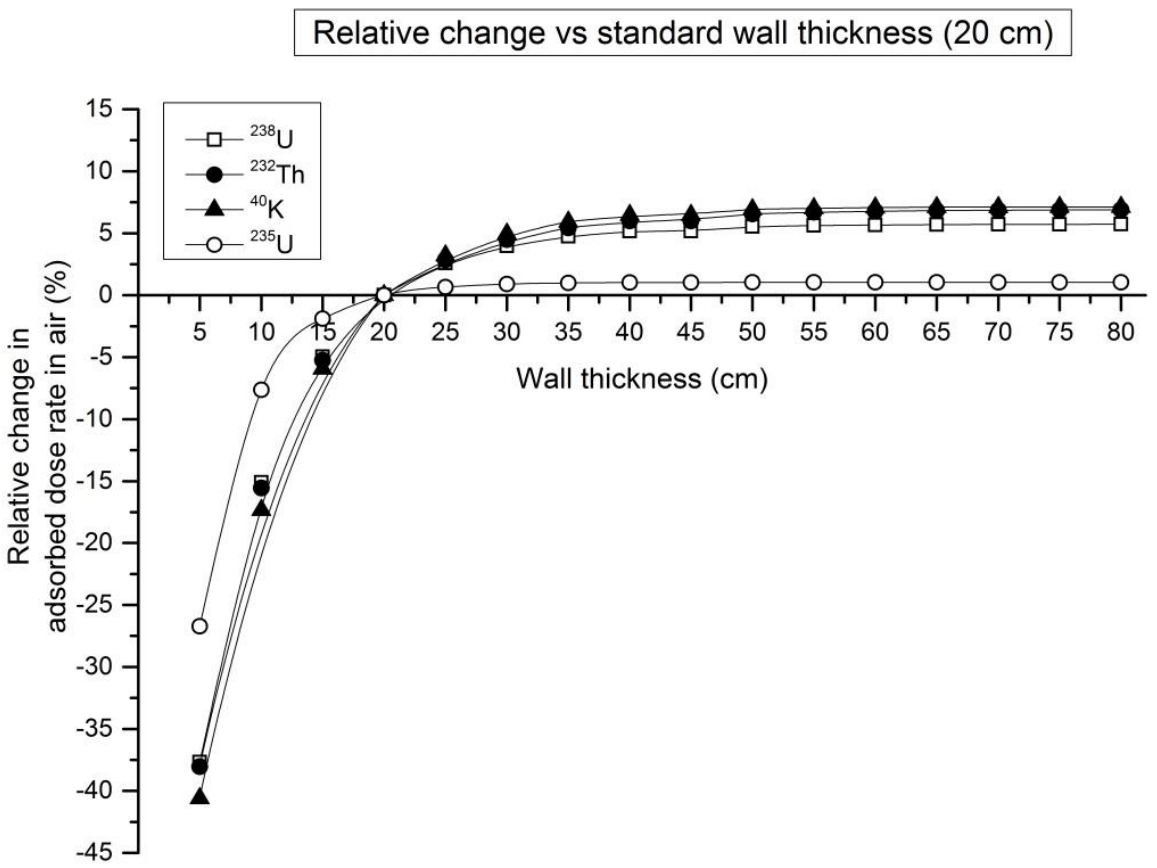

487

488

489

490

491

492

493

494

495

496

497

498

499

500

501

502

503

504

505

506

507

508

509

510

511

Figure 1: Relative change in the absorbed dose rate in air $\left(D_{A}\right)$ for a standard concrete room with varying thickness $(5-80 \mathrm{~cm})$ vs a standard concrete room with wall thickness of $20 \mathrm{~cm}$ for ${ }^{238} \mathrm{U},{ }^{232} \mathrm{Th},{ }^{40} \mathrm{~K}$ and ${ }^{235} \mathrm{U}$. Relative change: ( $D_{A}$ thickness $\mathrm{X}-\mathrm{D}_{\mathrm{A}}$ thickness $\left.20 \mathrm{~cm}\right) /\left(\mathrm{D}_{\mathrm{A}}\right.$ thickness $20 \mathrm{~cm} \mathrm{X}$ 100)

Figure 1 shows the relative change (\%) in $D_{A}$ air for different thicknesses relative to the wall thickness of $20 \mathrm{~cm}$ for ${ }^{238} \mathrm{U},{ }^{232} \mathrm{Th},{ }^{40} \mathrm{~K}$ and ${ }^{235} \mathrm{U}$ in a standard concrete room. It is observed that the relative decrease in $D_{A}$ occurs rapidly with decreasing wall thickness. In case of a wall thickness of $5 \mathrm{~cm}$ a relative decrease of $27.4 \%, 27.6 \%, 28.9 \%$ and $21.1 \%$ is observed for respectively ${ }^{238} \mathrm{U},{ }^{232} \mathrm{Th},{ }^{40} \mathrm{~K}$ and ${ }^{235} \mathrm{U}$. In case of a wall thickness of $80 \mathrm{~cm}$ a relative increase of $6.1 \%, 7.4 \%, 7.7 \%$ and $1.1 \%$ is observed for respectively ${ }^{238} \mathrm{U},{ }^{232} \mathrm{Th},{ }^{40} \mathrm{~K}$ and ${ }^{235} \mathrm{U}$. However, a plateau in the increase of the $D_{A}$ is observed. The percentage increase of the $D_{A}$ between 20 $\mathrm{cm}$ and $25 \mathrm{~cm}$ thickness is below $1 \%$ for ${ }^{235} \mathrm{U}$ whereas for the other radionuclides this is approximately $3 \%$. From a thickness of $40 \mathrm{~cm}$, the increase in the $D_{A}$ is below $1 \%$ per increase in $5 \mathrm{~cm}$ thickness for all the radionuclides. According to Risica et al. (2001) [27] this plateau originates from self-absorption effects.

As the floor thickness is not varied the contribution of the walls to the $D_{A}$ will increase with the thickness. The contribution of the smaller wall $(400 \mathrm{~cm})$ will increase with approximately $5 \%$ relative to the larger wall $(500 \mathrm{~cm})$ when increasing the wall thickness from $5 \mathrm{~cm}$ to 80 $\mathrm{cm}$.

\subsubsection{Impact of the density calculated by EGDA0\% model}




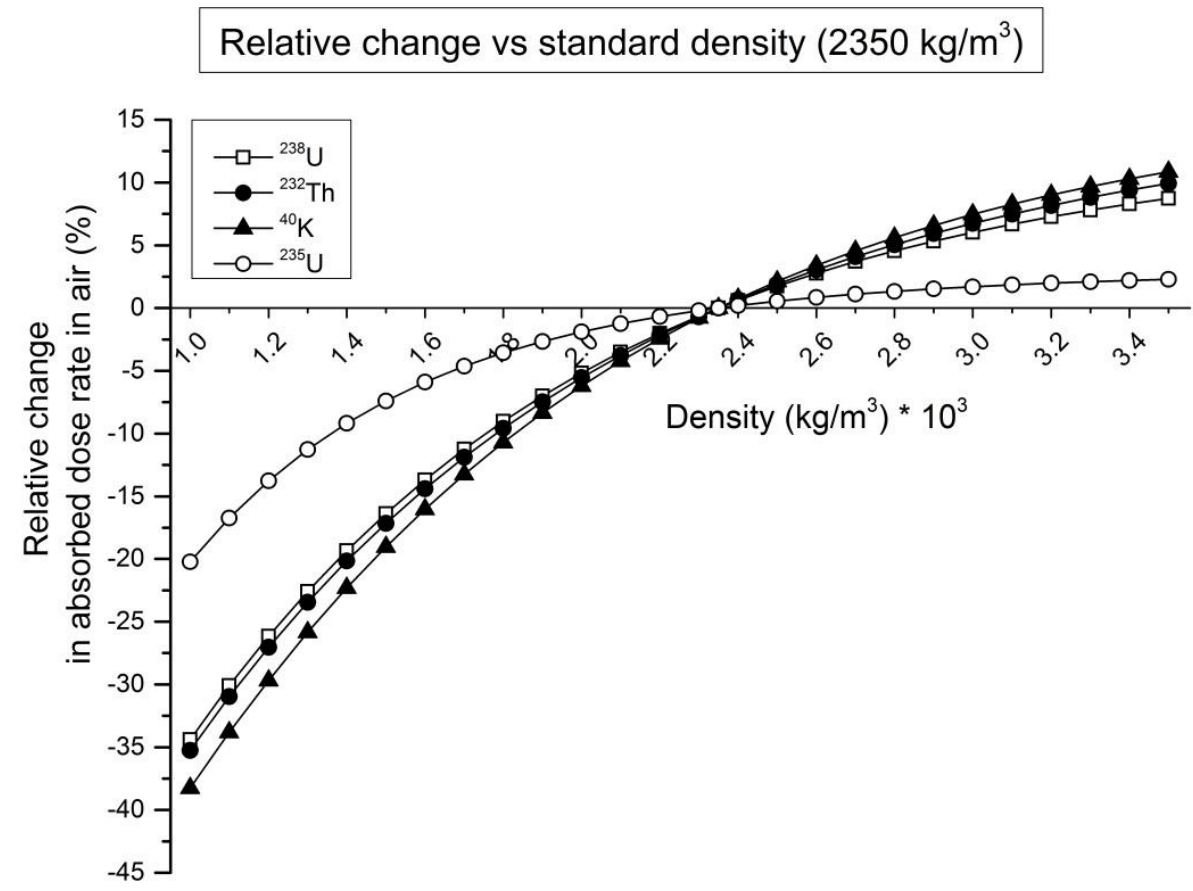

514 Figure 2: Relative difference of the absorbed dose rate in air $\left(D_{A}\right)$ for a standard concrete room with varying density $\left(1000-3500 \mathrm{~kg} / \mathrm{m}^{3}\right)$ vs a standard concrete room with density of 2350 $\mathrm{kg} / \mathrm{m}^{3}$ for ${ }^{238} \mathrm{U},{ }^{232} \mathrm{Th},{ }^{40} \mathrm{~K}$ and ${ }^{235} \mathrm{U}$. Relative change: ( $D_{A}$ densityx $-D_{A}$ density $2350 \mathrm{~kg} / \mathrm{m} 3$ )/ (DAdensity $2350 \mathrm{~kg} / \mathrm{m} 3 \times 100$ )

Figure 2 shows the difference in $D_{A}$ for different densities relative to the standard density of $2350 \mathrm{~kg} / \mathrm{m}^{3}$ for ${ }^{238} \mathrm{U},{ }^{232} \mathrm{Th},{ }^{40} \mathrm{~K}$ and ${ }^{235} \mathrm{U}$ in a standard concrete room with thickness of $20 \mathrm{~cm}$. At densities lower than $2350 \mathrm{~kg} / \mathrm{m}^{3}$ a relative decrease in $D_{A}$ is observed whereas a relative increase is observed at densities higher than $2350 \mathrm{~kg} / \mathrm{m}^{3}$. In case of a density of $1000 \mathrm{~kg} / \mathrm{m}^{3}$ a relative decrease of $34 \%, 35 \%, 38 \%$ and $20 \%$ is observed for respectively ${ }^{238} \mathrm{U},{ }^{232} \mathrm{Th},{ }^{40} \mathrm{~K}$ and ${ }^{235} \mathrm{U}$. In case of a density of $3500 \mathrm{~kg} / \mathrm{m}^{3} \mathrm{~cm}$ a relative increase of $9 \%, 10 \%, 11 \%$ and $2 \%$ is observed for respectively ${ }^{238} \mathrm{U},{ }^{232} \mathrm{Th},{ }^{40} \mathrm{~K}$ and ${ }^{235} \mathrm{U}$. With increasing densities the total number of radionuclides present in the material will increase leading to higher $D_{A}$. With decreasing densities to contrary is true.

With increasing densities the relative contribution of the floor and ceiling to total dose rate decreases with approximately $1 \%$ whereas the dose rate of the walls increases slightly. This effect is observed for the different radionuclides. 


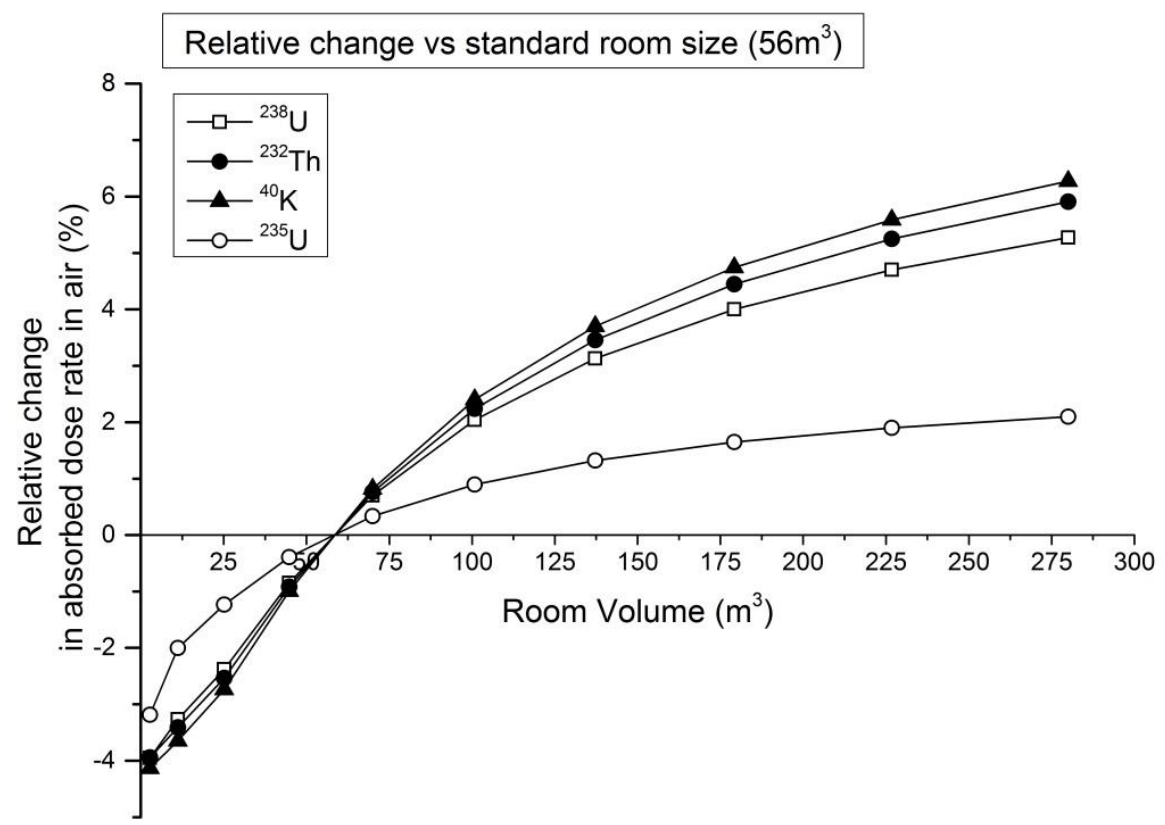

Figure 3: Relative difference of the absorbed dose rate in air for a standard concrete room with varying room size $\left(2.8-280 \mathrm{~m}^{3}\right)$ vs a standard concrete room with room size of $56 \mathrm{~m}^{3}$ for ${ }^{238} \mathrm{U},{ }^{232} \mathrm{Th},{ }^{40} \mathrm{~K}$ and ${ }^{235} \mathrm{U}$.

Figure 3 shows the difference in $D_{A}$ for different room sizes relative to the standard room size $\left(200 \times 250 \times 280 \mathrm{~cm}^{3}\right)$ for ${ }^{238} \mathrm{U},{ }^{232} \mathrm{Th},{ }^{40} \mathrm{~K}$ and ${ }^{235} \mathrm{U}$ in a standard concrete room. It is observed that the relative decrease in $D_{A}$ occurs with decreasing room size. In case of a room size of 2.8 $\mathrm{m}^{3}$ a relative decrease of $4 \%, 4 \%, 4 \%$ and $3 \%$ is observed for respectively ${ }^{238} \mathrm{U},{ }^{232} \mathrm{Th},{ }^{40} \mathrm{~K}$ and ${ }^{235} \mathrm{U}$. In case of a room size of $280 \mathrm{~m}^{3}$ a relative increase of $5 \%, 6 \%, 6 \%$ and $2 \%$ is observed for respectively ${ }^{238} \mathrm{U},{ }^{232} \mathrm{Th},{ }^{40} \mathrm{~K}$ and ${ }^{235} \mathrm{U}$. With increasing room size to person standing in the room is surrounded by more material. Consequently the total number of radionuclides present in the room will also increase, leading to higher $D_{A}$. With decreasing room size the contrary is true.

Figure 3 also shows that the influence of the room sizes affects the radionuclides differently.

Next to changing the room surface the impact of the room height is studied. At small room volumes (below approximately $15 \mathrm{~m}^{3}$ ), the $D_{A}$ of ${ }^{232} \mathrm{Th}$ is lower in case of a height of $200 \mathrm{~cm}$ than in case of a height of $280 \mathrm{~cm}$. For a room area of $1 \mathrm{~m}^{2}$ a difference of approximately 2.3 $\%, 2.5 \%, 2.7 \%$ and $1.2 \%$ difference for respectively ${ }^{238} \mathrm{U},{ }^{232} \mathrm{Th},{ }^{40} \mathrm{~K}$ and ${ }^{235} \mathrm{U}$ is observed. However at room size larger than $15 \mathrm{~m}^{3}$ the impact of height on the $D_{A}$ is reverted. At a room volume of $280 \mathrm{~m}^{3}$ an increase in the $\mathrm{D}_{\mathrm{A}}$ of $1.7 \%, 2.0 \%, 2.1 \%$ and $0.5 \%$ for respectively ${ }^{238} \mathrm{U}$, ${ }^{232} \mathrm{Th},{ }^{40} \mathrm{~K}$ and ${ }^{235} \mathrm{U}$ is observed in favour of the room height of $200 \mathrm{~cm}$.

\subsubsection{The impact of the presence of windows and doors by the EGDA $>0 \%$ model}


Table 7: \% Deviation in dose rate for different window surfaces located in the middle or the corner of Wall $1(400 \mathrm{~cm} \times 280 \mathrm{~cm})$, Wall $2(500 \times 280 \mathrm{~cm})$ and the ceiling $(400 \mathrm{~cm} \times 500 \mathrm{~cm})$ in comparison to respectively Wall 1 , Wall 2 and the ceiling without the presence of windows.

\begin{tabular}{|c|c|c|c|c|c|c|}
\hline & \multicolumn{2}{|c|}{ Window $100 \mathrm{~cm} \times 100 \mathrm{~cm}$} & \multicolumn{2}{|c|}{ Window $100 \mathrm{~cm} \times 200 \mathrm{~cm}$} & \multicolumn{2}{|c|}{ Window $200 \mathrm{~cm} \times 200 \mathrm{~cm}$} \\
\hline & Middle & Corner & Middle & Corner & Middle & Corner \\
\hline & \multicolumn{6}{|c|}{$\begin{array}{l}\text { \% Deviation in absorbed dose rate in air }\left(D_{A}\right) \text { originating from wall } 1(400 \mathrm{~cm} \times 280 \mathrm{~cm}) \\
\text { with a window in comparison wall } 1 \text { without a window }\end{array}$} \\
\hline${ }^{238} U$ & -11.8 & -7.3 & -22.5 & -21.1 & -43.2 & -36.6 \\
\hline${ }^{232} \mathrm{Th}$ & -11.8 & -7.3 & -22.5 & -21.1 & -43.1 & -36.6 \\
\hline${ }^{40} \mathrm{~K}$ & -11.7 & -7.4 & -22.4 & -21.0 & -43.0 & -36.6 \\
\hline \multirow[t]{2}{*}{${ }^{235} \mathrm{U}$} & -12.1 & -7.2 & -23 & -21.4 & -43.9 & -36.7 \\
\hline & \multicolumn{6}{|c|}{$\begin{array}{l}\text { \% Deviation in absorbed dose rate in air }\left(D_{A}\right) \text { originating from wall } 2(500 \mathrm{~cm} \times 280 \mathrm{~cm}) \\
\text { with a window in comparison to wall } 2 \text { without a window }\end{array}$} \\
\hline${ }^{238} U$ & -11.7 & -4.5 & -21.9 & -19.9 & -41.1 & -26.4 \\
\hline${ }^{232} \mathrm{Th}$ & -11.6 & -4.5 & -21.8 & -19.9 & -41.0 & -26.4 \\
\hline${ }^{40} \mathrm{~K}$ & -11.5 & -4.6 & -21.7 & -19.8 & -40.7 & -26.4 \\
\hline \multirow[t]{2}{*}{${ }^{235} \mathrm{U}$} & -12.2 & -4.3 & -22.6 & -20.4 & -42.2 & -26.1 \\
\hline & \multicolumn{6}{|c|}{$\begin{array}{c}\text { \% Deviation in absorbed dose rate in air }\left(D_{A}\right) \text { originating from a ceiling }(500 \mathrm{~cm} \times 400 \mathrm{~cm}) \\
\text { with a window in comparison to a ceiling without a window }\end{array}$} \\
\hline${ }^{238} U$ & -14.6 & -2.2 & -22.8 & -6.4 & -40.8 & -17.3 \\
\hline${ }^{232} \mathrm{Th}$ & -14.4 & -2.3 & -22.5 & -6.4 & -40.4 & -17.2 \\
\hline${ }^{40} \mathrm{~K}$ & -13.9 & -2.2 & -21.7 & -6.3 & -39.2 & -16.9 \\
\hline${ }^{235} U$ & -15.7 & -2.1 & -23.9 & -6.1 & -42.5 & -16.9 \\
\hline
\end{tabular}

566

567

568

569

570

571

572

573

574

575

576

577

578

579

580

581

582

Table 7 shows the percentage of deviation in the $D_{A}$ of the different room components in comparison to the standard concrete room. With increasing size of the window or door surface the $D_{A}$ of the component decreases. For example, in wall one the $D_{A}$ decreases with approximately $12 \%$ in case of a window of $100 \mathrm{~cm} \times 100 \mathrm{~cm}$ whereas this decrease is approximately $37 \%$ for a window of $200 \mathrm{~cm} \times 200 \mathrm{~cm}$. In both cases the windows are positioned in the middle of wall. Nevertheless the position of the surface in the component plays an important role. In wall 2 the $\mathrm{D}_{A}$ decreases for approximately $41 \%$ when the window is positioned in the middle of the wall. When the same window is positioned in the corner, the $D_{A}$ decreases with $26 \%$ in comparison to a standard concrete room. In addition it must be noted that in the case of a standard concrete room wall 1, wall 2 and the floor/ceiling contribute for approximately $9.5 \%, 14.5 \%$ and $26 \%$ respectively to the total $D_{A}$ of the room. The final influence on the $D_{A}$ due to the presence of a window in the ceiling will be larger than for a window in wall 1.

\subsection{Comparison of index and dose calculations}


Table 8: Overview of the index-values and effective dose (mSv/y) of the index and dose calculations used in the European legislative framework for different building materials consisting of residues or cement.

\begin{tabular}{|c|c|c|c|c|c|c|c|c|}
\hline \multirow{3}{*}{$\begin{array}{l}\text { Model } \\
\text { Thickness }(\mathrm{cm})\end{array}$} & \multicolumn{8}{|c|}{ Index } \\
\hline & \multirow{2}{*}{$\begin{array}{c}\mathrm{ACl} \\
20\end{array}$} & \multicolumn{7}{|c|}{$I(p d)$} \\
\hline & & 10 & 10 & 18 & 20 & 25 & 40 & 40 \\
\hline Density $\left(\mathrm{kg} / \mathrm{m}^{3}\right)$ & 2350 & 1400 & 3000 & 3000 & 2350 & 1400 & 1400 & 3000 \\
\hline Furnace slags & 0.788 & 0.384 & 0.628 & 0.811 & 0.770 & 0.678 & 0.822 & 1.006 \\
\hline $\begin{array}{l}\text { Bottom ash and fly } \\
\text { ash }\end{array}$ & 1.269 & 0.609 & 0.997 & 1.290 & 1.225 & 1.077 & 1.307 & 1.602 \\
\hline Phosphogypsum & 1.405 & 0.719 & 1.171 & 1.510 & 1.434 & 1.264 & 1.529 & 1.864 \\
\hline Bauxite residue & 3.592 & 1.657 & 2.710 & 3.509 & 3.330 & 2.928 & 3.554 & 4.355 \\
\hline Cement & 0.385 & 0.180 & 0.295 & 0.382 & 0.363 & 0.319 & 0.387 & 0.476 \\
\hline \multirow[t]{2}{*}{ Scenario number } & & 1 & 2 & 3 & & 4 & 5 & 6 \\
\hline & \multicolumn{8}{|c|}{ Dose (mSv/y) } \\
\hline Model & Mark orig & \multicolumn{7}{|c|}{$D(p d)$} \\
\hline Thickness (cm) & 20 & 10 & 10 & 18 & 20 & 25 & 40 & 40 \\
\hline Density $\left(\mathrm{kg} / \mathrm{m}^{3}\right)$ & 2350 & 1400 & 3000 & 3000 & 2350 & 1400 & 1400 & 3000 \\
\hline Furnace slags & 0.726 & 0.238 & 0.549 & 0.745 & 0.704 & 0.606 & 0.755 & 0.916 \\
\hline $\begin{array}{l}\text { Bottom ash and fly } \\
\text { ash }\end{array}$ & 1.293 & 0.521 & 1.017 & 1.329 & 1.264 & 1.108 & 1.346 & 1.604 \\
\hline Phosphogypsum & 1.592 & 0.659 & 1.237 & 1.595 & 1.521 & 1.342 & 1.614 & 1.905 \\
\hline Bauxite residue & 3.825 & 1.841 & 3.190 & 4.043 & 3.865 & 3.437 & 4.087 & 4.796 \\
\hline Cement & 0.206 & -0.019 & 0.128 & 0.222 & 0.202 & 0.155 & 0.227 & 0.304 \\
\hline \multirow[t]{2}{*}{ Scenario number } & & 1 & 2 & 3 & & 4 & 5 & 6 \\
\hline & & \multicolumn{7}{|c|}{ Dose (mSv/y) } \\
\hline \multicolumn{2}{|l|}{ Model } & \multicolumn{7}{|c|}{ EGDA $>0 \%$} \\
\hline \multicolumn{2}{|l|}{ Thickness $(\mathrm{cm})$} & 10 & 10 & 18 & 20 & 25 & 40 & 40 \\
\hline \multicolumn{2}{|l|}{ Density $\left(\mathrm{kg} / \mathrm{m}^{3}\right)$} & 1400 & 3000 & 3000 & 2350 & 1400 & 1400 & 3000 \\
\hline \multicolumn{2}{|l|}{ Furnace slags } & 0.238 & 0.557 & 0.736 & 0.697 & 0.590 & 0.712 & 0.813 \\
\hline \multicolumn{2}{|l|}{$\begin{array}{l}\text { Bottom ash and fly } \\
\text { ash }\end{array}$} & 0.520 & 1.029 & 1.317 & 1.254 & 1.083 & 1.279 & 1.441 \\
\hline \multicolumn{2}{|l|}{ Phosphogypsum } & 0.661 & 1.252 & 1.577 & 1.506 & 1.313 & 1.533 & 1.710 \\
\hline \multicolumn{2}{|l|}{ Bauxite residue } & 1.830 & 3.192 & 3.971 & 3.798 & 3.337 & 3.868 & 4.323 \\
\hline \multicolumn{2}{|l|}{ Cement } & -0.019 & 0.132 & 0.219 & 0.199 & 0.148 & 0.207 & 0.257 \\
\hline \multicolumn{2}{|l|}{ Scenario number } & 1 & 2 & 3 & & 4 & 5 & 6 \\
\hline
\end{tabular}

587

588

589

590

591

592

593

594
Table 8 shows different index and dose values for 5 types of building materials calculated via different models described in Table 2. It must be noted that different authors and models use different background reductions like mentioned in Table 2 . In addition in all calculations it is assumed that both the walls as the floor/ceiling have the same density and thickness. The $\mathrm{ACl}$ calculation is a non-flexible calculation and assumes a density of $2350 \mathrm{~kg} / \mathrm{m}^{3}$ and walls of 20 $\mathrm{cm}$ thick and is considered as a reference for comparison since this is screening tool prescribed by the EU-BSS. Looking at a building material with density of $2350 \mathrm{~kg} / \mathrm{m}^{3}$ and thickness of 20 
$\mathrm{cm}$, the index value of the $\mathrm{ACl}$ is higher than the index value of $\mathrm{I}(\rho \mathrm{d})$ except for the phosphogypsum composition.

In case of building materials lighter than $2350 \mathrm{~kg} / \mathrm{m}^{3}$ and thinner than $20 \mathrm{~cm}$ building materials, the $\mathrm{ACl}$ overestimates the index-value in comparison to I( $\rho \mathrm{d})$ (scenario 1 ). In scenario 2 and 3 the building material is thinner than $20 \mathrm{~cm}$ and heavier than $2350 \mathrm{~kg} / \mathrm{m}^{3}$. In scenario 2 solely overestimations by the $\mathrm{ACl}$ are observed. In scenario 3, an overestimation by the $\mathrm{ACl}$ only occurs in case of bauxite residue and cement. In contrast an underestimation occurs in case of furnace slags, bottom and fly ashes and phosphogypsum. In scenarios 4 and 5 the building material is lighter than $2350 \mathrm{~kg} / \mathrm{m}^{3}$ and thicker than $20 \mathrm{~cm}$. In scenario 4, the $\mathrm{ACl}$ overestimates the index value in comparison $\mathrm{I}(\rho \mathrm{d})$. In scenario 5 an overestimation by the $\mathrm{ACl}$ occurs in case of bauxite residue. In contrast an underestimation occurs in case of furnace slags, bottom and fly ashes, phosphogypsum and cement. Looking at building materials heavier than $2350 \mathrm{~kg} / \mathrm{m}^{3}$ and thicker than $20 \mathrm{~cm}$, the $\mathrm{ACl}$ underestimates the index-value (scenario 6).

In scenario 1 the $\mathrm{ACl}$ underestimates the index-value, it is recommended to use the I( $\rho \mathrm{d})$ when that $\mathrm{ACl}$ index value is above 1 . As in scenario 3 and 5 the $\mathrm{ACl}$ can over or underestimate the index value it is best to use the $I(\rho d)$. As the density and thickness parameters of scenario 2 and 4 correspond to the parameters of scenario 3 and 4 respectively, it is best to also use the $\mathrm{I}(\rho \mathrm{d})$ for scenario 2 and 4 . For scenario 6 the $\mathrm{ACl}$ underestimates the index value and from a radioprotection point of view $\mathrm{l}(\rho \mathrm{d})$ is recommended.

As underestimations by the Mark orig model (corresponds to $A C l$ ) in comparison to $D(\rho d)$ (corresponds to $\mathrm{I}(\rho \mathrm{d})$ ) occur in scenario $2,3,5$ and 6 , it is recommended from a radioprotection point of view to use the $D(\rho d)$ calculation. In other scenarios it is recommended to use the $D(\rho d)$ calculation when the effective dose approximates $1 \mathrm{mSv} / \mathrm{y}$.

Comparing the $D(\rho d)$ with $E G D A>0 \%$ one can see that the $D(\rho d)$-dose-values are for all scenarios higher than the ones calculated via EGDA>0\% except for scenario 1 and 2, which have a low wall thickness. In both scenarios, the EGDA>0\% gives an effective dose which is solely a few $\mu \mathrm{Sv} / \mathrm{y}$ higher. In scenario $3,4,5$ and 6 the EGDA $>0 \%$ gives a dose which is from the order of $10 \mu \mathrm{Sv} / \mathrm{y}$ to several 100's $\mu \mathrm{Sv} / \mathrm{y}$ lower. Therefore, in these scenarios, in case of an effective dose close to $1 \mathrm{mSv}$ calculated by $D(\rho \mathrm{d})$, the authors recommend using a more detailed dose assessment model like EGDA>0\% to more accurately assess the dose. It must also be noted that in this comparison the density and thickness of the walls and floor/ceiling are all equal. This can be different in reality and can affect the dose significantly. In addition one has to take into account that a room size larger than $400 \mathrm{~cm} \times 500 \mathrm{~cm} \times 280 \mathrm{~cm}$ gives rise to a dose increase like discussed in section 3.2.3. In addition, the presence of windows and doors will also impact this background correction as well as the different sample compositions.

Regarding the different residues, the $A C$ of a residue can vary according to the input, process parameters, etc. $[47,48]$. Therefore one cannot draw conclusions from the index and dose values of Table 8 on the usage of these classes of residues as building material but a case by case approach should be performed.

\section{Conclusion}


The current study provides a dose calculation assessment based on the original dose calculation of Markkanen with expanded number of gamma lines and higher total gamma intensity. It is shown that working with averaged gamma lines increases the absorbed dose rate in air for ${ }^{238} \mathrm{U}$ and ${ }^{232} \mathrm{Th}$ with $6.1 \%$ and $0.9 \%$ respectively in case of a standard concrete room. In contrast, a decrease of $4.6 \%$ is determined in case of ${ }^{235} \mathrm{U}$.

The presence of the build-up increases the absorbed dose rate in air and plays an important role in the final obtained dose received from building materials. In case the build-up is absent, a decrease in absorbed dose rate in air of $52 \%, 50 \%, 48 \%$ and $67 \%$ for respectively ${ }^{238} \mathrm{U}$, ${ }^{232} \mathrm{Th},{ }^{40} \mathrm{~K}$ and ${ }^{235} \mathrm{U}$ is observed. In case of the ISSPelli model, the use of the Pelliccioni Berger parameters lowered the absorbed dose rate in air with $2.8 \%$ and $2.6 \%$ for respectively ${ }^{238} \mathrm{U}$ and ${ }^{232} \mathrm{Th}$ in comparison with the ISS orig model, which uses the Berger parameters described by Markkanen. Further improvements on the accuracy of the $B$ and consequently the absorbed dose rate in air can be made by working with build-up factors customized towards the chemical composition of the building material with for example a geometric progression approach [49].

The developed EGDA $>0 \%$ model is complementary to the existing $\mathrm{ACl} /$ original Markkanen model and $\mathrm{I}(\rho \mathrm{d}) / \mathrm{D}(\rho \mathrm{d})$ index/dose calculations which prove relevant for the dose assessment within the European legislative framework applicable towards building materials. Due to its simplicity the authors recommend to perform a first screening by using the $\mathrm{ACl}$ proposed by the EU-BSS in the case of building materials thinner than $20 \mathrm{~cm}$ or lighter than $2350 \mathrm{~kg} / \mathrm{m}^{3} . \mathrm{In}$ the case of a building material thicker than $20 \mathrm{~cm}$ or heavier than $2350 \mathrm{~kg} / \mathrm{m}^{3}$, the authors propose to use $D(\rho d)$ calculation tool of Nuccetelli et al. [2] in case of standard room sizes. In case the resulting dose of this calculation exceeds $1 \mathrm{mSv} / \mathrm{y}$ one should perform a more detailed dose assessment. The EGDA>0\% model can be used for these specific cases. The EGDA $>0 \%$ model also allows coping with non-standard room sizes or the presence of doors and windows The model does not consider the dose originated by $222 \mathrm{Rn}$ exhalation resulting in an overestimation of the total external gamma dose originating from building materials.

A sensitivity analysis was performed of the EGDA $>0 \%$ model. The main factors that contribute to increase the absorbed dose rate in air in comparison to a standard concrete room (Volume of $56 \mathrm{~m}^{3}$; density of $2350 \mathrm{~kg} / \mathrm{m}^{3}$; wall/floor/ceiling thickness of $20 \mathrm{~cm}$ ) are

- Increasing density; in case of $3500 \mathrm{~kg} / \mathrm{m}^{3}$ an increase of $9 \%, 10 \%, 11 \%$ and $2 \%$ for respectively ${ }^{238} \mathrm{U},{ }^{232} \mathrm{Th},{ }^{40} \mathrm{~K}$ and ${ }^{235} \mathrm{U}$ is observed.

- Increasing thickness; in case of $80 \mathrm{~cm}$ thick walls an increase of $6 \%, 7 \%, 8 \%$ and $1 \%$ for respectively ${ }^{238} \mathrm{U},{ }^{232} \mathrm{Th},{ }^{40} \mathrm{~K}$ and ${ }^{235} \mathrm{U}$ is observed.

- Increasing volume; in case of a room volume of $280 \mathrm{~m}^{3}$ an increase of $5 \%, 6 \%, 6 \%$ and $2 \%$ for respectively ${ }^{238} \mathrm{U},{ }^{232} \mathrm{Th},{ }^{40} \mathrm{~K}$ and ${ }^{235} \mathrm{U}$ is observed.

The main factors that contribute to decrease the absorbed dose rate in air in comparison to a standard concrete room are: 
- Decreasing density; in case of $1000 \mathrm{~kg} / \mathrm{m}^{3}$ a decrease of $34 \%, 35 \%, 38 \%$ and $20 \%$ for respectively ${ }^{238} \mathrm{U},{ }^{232} \mathrm{Th},{ }^{40} \mathrm{~K}$ and ${ }^{235} \mathrm{U}$ is observed.

- Decreasing thickness; in case of $5 \mathrm{~cm}$ thick walls a decrease of $27 \%, 28 \%, 29 \%$ and $21 \%$ for respectively ${ }^{238} \mathrm{U},{ }^{232} \mathrm{Th},{ }^{40} \mathrm{~K}$ and ${ }^{235} \mathrm{U}$ is observed.

- Decreasing volume; in case of a volume of $2.8 \mathrm{~m}^{3}$ a decrease of $4 \%, 4 \%, 4 \%$ and $3 \%$ for respectively ${ }^{238} \mathrm{U},{ }^{232} \mathrm{Th},{ }^{40} \mathrm{~K}$ and ${ }^{235} \mathrm{U}$ is observed.

- Presence of windows or doors; in case of one window of $2 \times 2 \mathrm{~m}$ in wall 1 a decrease of $4 \%$ for ${ }^{238} \mathrm{U},{ }^{232} \mathrm{Th},{ }^{40} \mathrm{~K}$ and ${ }^{235} \mathrm{U}$ is observed.

In addition, the shape of the room can also impact the absorbed dose rate in air. Also the position and size of the window or door in the wall will impact the final absorbed dose rate in air. Larger windows positioned in the middle of the wall lead to a lower absorbed dose rate in air. The implementation of the chemical composition in the model via the attenuation coefficients showed limited effects on the absorbed dose rate in air. For a standard room an increase of $1.4 \%, 0.9 \%$ and $2.1 \%$ is observed for ${ }^{238} \mathrm{U},{ }^{232} \mathrm{Th}$ and ${ }^{40} \mathrm{~K}$ in case of a FSIP sample composition in comparison to a concrete sample composition. In contrast, a decrease of $6.8 \%$ in case of ${ }^{235} \mathrm{U}$ is observed.

Although the Markkanen room model is widely spread and used as a conservative screening tool in European legislation, the uncertainty of the method should be assessed. The expansion proposed here expands the model with validated scientific date but does not take care of the uncertainty. The uncertainty assessment is a topic for further research.

\section{Acknowledgement}

This work was supported by the COST Action TU1301. www.norm4building.org.

\section{References}

[1] M. Markkanen, Radiation Dose Assessments for Materials with Elevated Natural Radioactivity, Finish Cent. Radiat. Nucl. Safety. Rep. STUK-B-STO 32. (1995) 1-41.

[2] C. Nuccetelli, F. Leonardi, R. Trevisi, A new accurate and flexible index to assess the contribution of building materials to indoor gamma exposure, J. Environ. Radioact. 143 (2015) 70-75. doi:10.1016/j.jenvrad.2015.02.011.

[3] United Nations, Sources and Effects of Ionizing Radiation United Nations Scientific Committee on the Effects of Atomic Radiation UNSCEAR 2000 Report to the General Assembly, with Scientific Annexes VOLUME I: SOURCES, 2000.

[4] European Council, Laying down basic safety standards for protection against the dangers arising from exposure to ionising radiation, and repealing directives 89/618/Euratom, 90/641/Euratom, 96/29/Euratom, 97/43/Euratom and 2003/122/Euratom, Off. J. Eur. Union. (2014) 1-73.

[5] European Commission, A resource-efficient Europe - Flagship initiative under the Europe 2020 Strategy, (2011).

[6] European Commission, A strategy for smart, sustainable and inclusive growth, (2010). [7] European Commission, Roadmap to a resource efficient Europe, (2011). 
[8] W. Schroeyers, T. Croymans-Plaghki, S. Schreurs, Towards a holistic approach for risk assessment when reusing slag with enhanced NORM content in building materials, 4th Int. Slag Valoris. Symp. (2015).

[9] Y. Pontikes, R. Snellings, Cementitious binders incorporating residues, in: Handb. Recycl., 2014: p. 219-229. doi:10.1016/B978-0-12-396459-5.00016-7.

[10] C. Nuccetelli, Y. Pontikes, F. Leonardi, R. Trevisi, New perspectives and issues arising from the introduction of (NORM) residues in building materials: A critical assessment on the radiological behaviour, Constr. Build. Mater. 82 (2015) 323-331. doi:10.1016/j.conbuildmat.2015.01.069.

[11] R. Siddique, I.M. Khan, Supplementary Cementing Materials, 2011. doi:10.1017/CBO9781107415324.004.

[12] D.V. Ribeiro, J.A. Labrincha, M.R. Morelli, Use of Calcined Bauxite Waste as a Supplementary Cementitious Material: Study of Pozzolanic Activity, J. Mater. Sci. Eng. 4 (2014) 172-178.

[13] T. Croymans, I. Vandael Schreurs, M. Hult, G. Marissens, L. Guillaume, H. Stroh, S. Schreurs, W. Schroeyers, Variation of natural radionuclides in non-ferrous fayalite slags during a one-month production period, J. Environ. Radioact. (2016).

[14] R. Trevisi, S. Risica, M. D'Alessandro, D. Paradiso, C. Nuccetelli, Natural radioactivity in building materials in the European Union: A database and an estimate of radiological significance, J. Environ. Radioact. 105 (2012) 11-20. doi:10.1016/j.jenvrad.2011.10.001.

[15] L. Koblinger, Calculation of exposure rates from gamma sources in walls of dwelling rooms, Health Phys. 34 (1978) 459-463.

[16] E. Stranden, Radioactivity of building materials and the gamma radiation in dwellings, Phys. Med. Biol. 24 (1979) 921-930.

[17] S. Righi, S. Verità, P.L. Rossi, M.F. Maduar, A dose calculation model application for indoor exposure to two-layer walls gamma irradiation: the case study of ceramic tiles, Radiat. Prot. Dosimetry. 171 (2016) 545-553. doi:10.1093/rpd/ncv476.

[18] P. de Jong, W. van Dijk, Modeling gamma radiation dose in dwellings due to building materials., Health Phys. 94 (2008) 33-42. doi:10.1097/01.HP.0000278509.65704.11.

[19] J. Deng, L. Cao, X. Su, Monte Carlo simulation of indoor external exposure due to gamma-emitting radionuclides in building materials, Chinese Phys. C. 38 (2014) 108202. doi:10.1088/1674-1137/38/10/108202.

[20] M. Zeeshan Anjum, S.M. Mirza, M. Tufail, N.M. Mirza, Z. Yasin, Natural radioactivity in building materials: dose determination in dwellings using hybrid Monte Carlodeterministic approach, Int. Conf. Nucl. Data Sci. Technol. (2007) 1-4. doi:10.1051/ndata:07187.

[21] N.M. Mirza, S. Mirza, A Shape and Mesh Adaptive Computational Methodology for Gamma Ray Dose from Volumetric Sources, Radiat. Prot. Dosimetry. 38 (1991) 307314. doi:10.1093/oxfordjournals.rpd.a081106.

[22] R. Mustonen, Methods for evaluation of doses from building materials, Radiat. Prot. Dosimetry. 7 (1984) 235-238.

[23] C. Nuccetelli, S. Risica, M.D. Alessandro, R. Trevisi, Natural radioactivity in building material in the European Union : robustness of the activity concentration index I and comparison with a room model, J. Radiol. Prot. 32 (2012) 349-358. doi:10.1088/09524746/32/3/349.

[24] V. Manić, G. Manić, D. Nikezic, D. Krstic, Calculation of Dose Rate Converstion Factors 
for 238U, 232Th and 40K in Concrete Structures of Various Dimensions, With Application To Nis, Serbia, Radiat. Prot. Dosimetry. 152 (2012) 361-368.

[25] V. Manić, D. Nikezic, D. Krstic, G. Manić, Assessment of indoor absorbed gamma dose rate from natural radionuclides in concrete by the method of build-up factors, Radiat. Prot. Dosimetry. 162 (2014) 609-617. doi:10.1093/rpd/nct358.

[26] B. Chen, Q. Wang, W. Zhuo, Assessment of gamma dose rate in dwellıngs due to Decoratıve stones., Radiat. Prot. Dosimetry. 166 (2015) 1-4. doi:10.1093/rpd/ncv256.

[27] S. Risica, C. Bolzan, C. Nuccetelli, Radioactivity in building materials: room model analysis and experimental methods., Sci. Total Environ. 272 (2001) 119-126.

[28] European Commission, Radiation protection 112 Radiological protection principles concerning the natural radioactivity of building materials, (1999) 1-16.

[29] R. Mustonen, Methods for evaluation of radiation from building materials, Radiat. Prot. Dosimetry. 7 (1985) 235-238.

[30] European Commission, Radiation protection 122 practical use of the concepts of clearance and exemption Part II application of the concetps of exemption and clearance to natural radiation sources, 2002.

[31] Laboratoire national Henri Becquerel, Decay Data Evaluation Project, (2016). http://www.nucleide.org/DDEP.htm (accessed May 22, 2016).

[32] NIST, Composition of Concrete, Portland, (n.d.) 1. http://physics.nist.gov/cgibin/Star/compos.pl?matno=144.

[33] J.E. Martin, Physics for radiation protection, WILEY-VCH Verlag GmbH \& Co. KGaA $2^{\text {nd }}$ Edition, 2006.

[34] J.H. Hubbell, S.M. Seltzer, Tables of $x$-ray mass attenuation coefficients and mass energy-absorption coefficients $1 \mathrm{keV}$ to $20 \mathrm{meV}$ for elements $\mathrm{z}=1$ to 92 and 48 additional substances of dosimetric interest, 1995.

[35] M. Pelliccioni, Fondamenti fisici della radioprotezione, Pitagora, 1989.

[36] D. Krstic, D. Nikezic, Calculation of Indoor Effective Dose factors in Ornl Phantoms Series Due to Natural Radioactivity in Building Materials, Health Phys. 97 (2009) 299302.

[37] R Devellopment Core Team, R: A language and environment for statistical computing. R Foundation for Statistical Computing, Vienna, Austria., (2008). http://www.rproject.org.

[38] J.H. Hubbell, Photon mass attenuation and energy-absorption coefficients, Int. J. Appl. Radiat. Isot. 33 (1982) 1269-1290.

[39] M.J. Berger, J.H. Hubbell, S.M. Seltzer, J. Chang, J.S. Coursey, R. Sukumar, D.S. Zucker, K. Olsen, XCOM: Photon Cross Sections Database, NIST Stand. Ref. Database 8. (2010) 1-5. http://www.nist.gov/pml/data/xcom/.

[40] IAEA, NuDat, (n.d.). http://www.nndc.bnl.gov/nudat2/.

[41] L. Kriskova, P.T. Jones, H. Jannsen, B. Blanpain, Y. Pontikes, Synthesis and Characterisation of Porous Inorganic Polymers from Fayalite Slag., Slag Valoris. Symp. Zero Waste. 4 (2015) 227-230.

[42] S. Onisei, K. Lesage, B. Blanpain, Y. Pontikes, Early Age Microstructural Transformations of an Inorganic Polymer Made of Fayalite Slag, J. Am. Ceram. Soc. 9 (2015) 1-9. doi:10.1111/jace.13548.

[43] R.I. Iacobescu, V. Cappuyns, T. Geens, L. Kriskova, S. Onisei, P.T. Jones, Y. Pontikes, The influence of curing conditions on the mechanical properties and leaching of inorganic polymers made of fayalitic slag, Front. Chem. Sci. Eng. (2017) 208-213. 
doi:10.1007/s11705-017-1622-6.

827

[44] M. Berger, J. Hubbell, XCOM: Photon cross sections on a personal computer, Natl. Bur. Stand. Washington, DC (USA). Cent. Radiat. Res. (1987) 1-28. doi:10.2172/6016002.

[45] M. Marangoni, L. Arnout, L. Machiels, L. Pandelaers, E. Bernardo, P. Colombo, Y. Pontikes, C. Jantzen, Porous, Sintered Glass-Ceramics from Inorganic Polymers Based on Fayalite Slag, J. Am. Ceram. Soc. 99 (2016) 1-7. doi:10.1111/jace.14224.

[46] T. Hertel, B. Blanpain, Y. Pontikes, A Proposal for a $100 \%$ Use of Bauxite Residue Towards Inorganic Polymer Mortar, J. Sustain. Metall. 2 (2016) 394-404. doi:10.1007/s40831-016-0080-6.

[47] IAEA, Extent of Environmental Contamination by Naturally Occurring Radioactive Material (NORM) and Technological Options for Mitigation - Technical reports series no. 419, 2003.

[48] T. Croymans, I. Schreurs, M. Hult, G. Marissens, H. Stroh, G. Lutter, S. Schreurs, W. Schroeyers, Variation of natural radionuclides in non-ferrous fayalite slags during a one-month production period, J. Environ. Radioact. 172 (2017) 63-73. doi:10.1016/j.jenvrad.2017.03.004.

[49] Y. Harima, Validity of the Geometric-Progression Formula in approximating GammaRay Buildup Factors, Nucl. Sci. Eng. 5 (1986) 24-35. 